Clim. Past Discuss., doi:10.5194/cp-2017-39, 2017

Manuscript under review for journal Clim. Past

Discussion started: 16 March 2017

(c) Author(s) 2017. CC-BY 3.0 License.

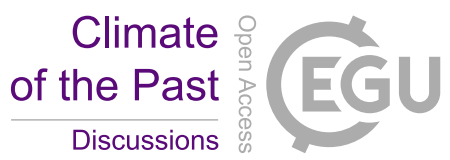

\title{
Historical Climate off the Atlantic Iberian Peninsula
}

\author{
Abrantes $^{1,2}$, Fátima; Teresa Rodrigues ${ }^{1,2}$, Marta Rufino ${ }^{2,3}$; Emília Salgueiro ${ }^{1,2}$; Dulce Oliveira ${ }^{1,2,4}$; \\ Sandra Gomes ${ }^{1}$; Paulo Oliveira ${ }^{1}$; Ana Costa ${ }^{5}$; Mário Mil-Homens ${ }^{1}$; Teresa Drago ${ }^{1,6}$; Filipa Naughton ${ }^{1,2}$, \\ 1 -Portuguese Institute for the Ocean and Atmosphere (IPMA), Divisão de Geologia Marinha (DivGM), Rua Alferedo \\ 5 \\ Magalhães Ramalho 6, Lisboa, Portugal \\ 2 - CCMAR, Centro de Ciências do Mar, Universidade do Algarve, Campus de Gambelas, 8005-139 Faro, Portugal \\ 3 - IFREMER - Centre Atlantique (French Research Institute for Exploitation of the Sea, Département Ecologie et \\ Modèles pour l'Halieutique (EMH), Rue de l'Ile d'Yeu - BP 21105, 44311 Nantes cedex 3, France \\ 4 - Univ. Bordeaux, EPOC, UMR 5805, F-33615 Pessac, France \\ 10 \\ 5 - Centro de Investigação em Biodiversidade e Recursos Genétics (EnvArchCIBIO/InBIO) and Archaeosciences \\ Laboratory (LARC/DGPC), Rua da Bica do Marquês, 2, 1300-087, Lisboa, Portugal \\ 6 - Instituto Dom Luiz, Universidade de Lisboa, 1749-016 Lisboa, Portugal \\ Correspondence to: Fatima Abrantes (Fatima.abrantes@ipma.pt)
}

Key Words - Last 2ky, climate, SST, Precipitation, Iberian Peninsula

\begin{abstract}
The Iberian Peninsula, at North Atlantic mid-latitude and the western extreme of the European continent, is a key point for climate reconstructions. This work provides multi-proxy records measured in 8 inner-shelf sediment cores from 5 sites located between South Portugal (Algarve) and Northwest Spain (Galiza) ( 36 to $41^{\circ} \mathrm{N}$ ) and target a regional reconstruction of climate variability during the Historic period (last $2 \mathrm{ky}$ ).

The SST records reveal a long-term scale cooling $\left( \pm 1^{\circ} \mathrm{C} / 2 \mathrm{ky}\right)$ that ends at the beginning of the $20^{\text {th }}$ century at all latitudes. This cooling is a follow up of the cooling process that started in the early Holocene driven by a decrease in summer insolation in the Northern Hemisphere.

25 Within this long term SST variability multi-decadal/ centennial scale variability is detected along Iberia. The different latitudinal SST reconstructions jointly with a determined regional SST stack were compared to on-land precipitation from higher plant n-alkanes and pollen data, to assess the relationship between hydroclimate (drought and/or precipitation) and SST. Regional variability is overall in consonance with NE Spain, and other European and north Hemisphere reconstructions. Warm
\end{abstract}


Clim. Past Discuss., doi:10.5194/cp-2017-39, 2017

Manuscript under review for journal Clim. Past

Discussion started: 16 March 2017

(c) Author(s) 2017. CC-BY 3.0 License.

conditions prevailed throughout $1300 \mathrm{yr}$, encompassing the Roman Period (RP), the Dark Ages (DA) and the Medieval Warm Period (MWP). The initial cooling at $1300 \mathrm{CE}$ leads to 4 centuries of $\pm 1^{\circ} \mathrm{C}$ colder mean SSTs contemporaneous with the Little Ice Age (LIA). The transition towards the Industrial Era starts by $1800 \mathrm{CE}$ with a rise to pre-LIA SSTs. Climate specificities have been detected in western Iberian margin records and reveal the existence of two distinct phases within the MWP and a two-step SST increase towards the Industrial Era. The intense precipitation/ flooding and warm winters but cooler intermediate seasons observed for the early MWP imply the interplay of internal oceanic variability with the three known atmospheric circulation modes, NAO, EA and SCAND in a positive phase. The late MWP, typified by drier and cooler winters and warmer intermediate seasons calls for a change in sign of the SCAND. A stronger mark of oceanic influences on western Iberian Peninsula (IP) starts with the transition to the Industrial Era.

\section{Introduction}

Today's climate goes through a warming shift caused by the increased release of human-generated greenhouse gases, such as $\mathrm{CO}_{2}$, and poses a pressing problem on societies' sustainability (IPCC, 2013b). $\mathrm{CO}_{2}$ uptake by the ocean (Sabine, 2004), although helping to control atmospheric temperature, it is changing ocean's temperature and chemistry, mainly lowering the oceans' $\mathrm{pH}$ (acidification). Ocean warming, on the other side, is driving changes in atmospheric and oceanic circulation patterns. Additionally, the Mediterranean region has been highlighted as one of the most sensitive region to the ongoing global climatic changes (Giorgi, 2006). Increasing temperatures to higher values than the predicted global mean and changes in precipitation in the Iberian Peninsula (IP), accompanied by long dry summers and a short and wetter rainy season, are projected both by global and regional model simulations in particular for its southern region (Miranda et al., 2002), making it one of the European regions with highest potential vulnerability in regard to current global warming (Climate, 2011).

Most of this knowledge is based on the analysis of instrumental data and modeling of global and hemispheric average conditions. However, given the limited time-span covered by the instrumental data, to better understand the impact of climate warming it is essential to analyze and understand the response of the system in perspective of a longer time-scale, and investigate previous warm periods and warming transitions such as those occurring over the historical times (last 2,000 years). Records and model reconstructions (Fernandez-Donado et al., 2013) identified solar and volcanic activity, greenhouse gases, and land-use changes as the main external drivers of the global climate shifts during the last millennium (Hegerl et al., 2006), while (Schurer et al., 2014) defends greenhouse gases concentration and volcanic eruptions as the main drivers of atmospheric temperature changes in the northern Hemisphere. In general, a large number of reconstructions find a Medieval Warm Period (MWP) / Medial Climate Anomaly (MCA), that lasted from 900 to $1300 \mathrm{CE}$, associated to high solar 
Clim. Past Discuss., doi:10.5194/cp-2017-39, 2017

Manuscript under review for journal Clim. Past

Discussion started: 16 March 2017

(c) Author(s) 2017. CC-BY 3.0 License.

Ice Age (LIA), which extended between 1350 and 1850 CE (Jones et al., 2001). After 1900 CE, global mean atmospheric temperature rise became mainly an effect of the huge increase of greenhouses gases in the atmosphere (IPCC, 2013b).

Over the last two decades, many Iberian lake sediments (e.g. (Hernández et al., 2015; JambrinaEnríquez et al., 2016; Morellón et al., 2009; Moreno et al., 2008; Valero-Garcés et al., 2006); speleothems (e.g. (Martín-Chivelet et al., 2011) and marine sediments (e.g (Abrantes et al., 2005; Abrantes et al., 2011; Lebreiro et al., 2006; Pena et al., 2010), have provided individual records and compiled evaluations of climate evolution over Iberia during the historical period (e.g. (Moreno et al., 2011; Sánchez-López et al., 2016). Results reveal multi-decadal to centennial climate variability, manifesting a MWP and a LIA, in accordance with the main pattern encountered for the north Atlantic, although the expected complex regional differences appear reflected by the lack of agreement on the exact timing and duration of those two most important historic climatic periods (e.g. (Ahmed et al., 2013; Büntgen et al., 2011; Cook et al., 2004; Esper et al., 2002; Luterbacher et al., 2004; Luterbacher et al., 2016; Moberg et al., 2005). Additionally, given the dominance of the large-scale climate mode operating in the Northern Hemisphere, the North Atlantic Oscillation (NAO) (Hurrell, 1995), most of the above referred studies attribute the inferred variability to changes in the prevailing modes of the NAO. Being mainly a winter season mode, NAO phases, defined from the strength and positions of the Icelandic Low and the Azores High pressure systems, vary on scales of days to decades. The effects of its variability translate into strong northerly winds during positive NAO periods, while westerly/ southwesterly winds become predominant and result in very cold winters and increased storm activity during NAO negative phases (also known as "blocked") (Hurrell, 1995; Trigo et al., 2004). That leads to an attribution of the warm and dry conditions of the MWP to a dominance of the $\mathrm{NAO}+$ conditions, and the more cold and humid conditions of the LIA to the dominance of a negative NAO.

Other prominent modes of climate, the East Atlantic (EA) and the Scandinavia (SCAND) (Comas-Bru and McDermott, 2014; Jerez and Trigo, 2013), constitute second leading modes, which interplay with the NAO, and their temporal variability, must have also had a role on the climatic evolution of the north Atlantic. The EA has a strong effect on the strength and location of the NAO dipoles mainly on a multidecadal time-scale, and according to (Hernández et al., 2015), has a major control on winter and summer temperature over the Iberian Peninsula. The SCAND pattern, functions as a blocking highpressure system that changes the westerly winds path and influences southwestern Europe mainly during its positive phase, when it contributes to temperatures below average and above average precipitation (e.g. (Jerez and Trigo, 2013)). Sánchez-Lopez et al., (2016), on the basis of a spatiotemporal integration of several reconstructions, attempt to identify the role of those main climatic drivers over the Iberian Peninsula. Their results reveal the existence of E-W and N-S humidity gradients from 0 to $500 \mathrm{CE}$ and between 500 and $900 \mathrm{CE}$ respectively, while between 900 and $1850 \mathrm{CE}$ temperature and humidity conditions are more homogenous throughout the Peninsula. Using the EOF- 
Clim. Past Discuss., doi:10.5194/cp-2017-39, 2017

Manuscript under review for journal Clim. Past

Discussion started: 16 March 2017

(c) Author(s) 2017. CC-BY 3.0 License.

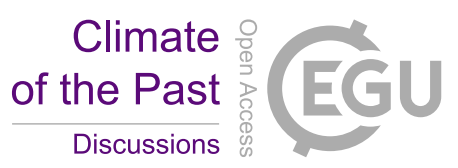

based indices for different NAO and EA indices of (Comas-Bru and McDermott, 2014), the authors propose equally negative NAO and EA during the LIA, as well as an equally positive NAO and EA during the MWP. On the contrary, NAO- and EA+ would explain the warm temperatures and E-W humidity gradient before $500 \mathrm{CE}$, while the inverse conditions between $500-900 \mathrm{CE}$ could be explained by a NAO+ but EA-. These conclusions support atmospheric pathways as the main control of climate variability in Western Europe on multi-decadal time-scales. However, the ocean side is poorly represented ( 2 reconstructions) relatively to the mountainous interior and it has for long been accepted that Western Europe winter temperatures are influenced by the heat transported to the east by the Gulf Stream and its North Atlantic Current extension (Palter, 2015). (Wang and Dong, 2010) on the other hand, consider that North Atlantic temperature variability at decadal scale, the Atlantic Multidecadal Oscillation/ Variability (AMO/AMV), goes beyond the influence of neighbor continents, contributing also to global SST variability. The work of (Yamamoto and Palter, 2016) shows a clear relation between the NAO derived atmospheric circulation over Europe and the AMO, with northerly winds associated to a positive state of AMO and zonal winds to a negative state of AMO. But, although the same authors find a clear imprint of AMO variability in European temperature in summer, such does not happen during winter. From the analysis of a $70 \mathrm{yr}$ (1940-2011) dataset of SST and Western European surface atmospheric temperature and particle trajectory modeling, (Yamamoto and Palter, 2016) attribute the absence of a winter signal to a cancelation of the ocean SST expression by strong cold winds. The two reconstructions from the Iberian/Atlantic ocean region (Abrantes et al, 2005; 2011), indicate coastal upwelling variability not only in consonance with inferred NAO conditions but also coherence with the instrumentally and tree-ring reconstructed Atlantic Multidecadal Oscillation (AMO) (Gray et al., 2004), suggesting a connection between the IP coastal circulation and the North Atlantic Ocean SSTs.

25 Given the risk to climate warming derived threats for ecosystems and society estimated for Western Iberia, both at global and European level, high-resolution climate archives for the most recent centuries and millennia are pivotal to better understand the interactions of the various modes of variability in future scenarios of climate and their relevance to the IP region.

The purpose of this work is to investigate the latitudinal and temporal variation of winter precipitation over the Westernmost European territory, the Western Iberian Peninsula, as well as oceanic SST behavior on decadal to multi-decadal scales. For that we combine the above mentioned published records with 5 new records, covering the last 2 millennia, and spanning along the Iberian margin from $41^{\circ} \mathrm{N}$ to $36^{\circ} \mathrm{N}$. Furthermore, a regional SST stack of the last 2,000 yr was developed and compared to proxy and model derived reconstructions of forcing factors and environmental properties. 
Clim. Past Discuss., doi:10.5194/cp-2017-39, 2017

Manuscript under review for journal Clim. Past

Discussion started: 16 March 2017

(c) Author(s) 2017. CC-BY 3.0 License.

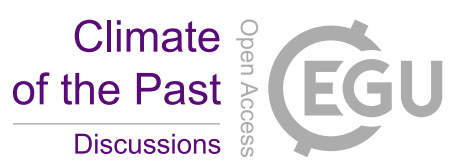

The western coast of the Iberian Peninsula is characterized by the occurrence of contrasting oceanographic conditions between a quasi-permanent coastal upwelling regime and a surface equatorward current in summer (April to October) (Fiuza, 1982, 1983; Peliz, 2002), and a poleward alongshore warm counter current in winter (Fiuza and Frouin, 1986; Peliz et al., 2005).

5 The spring-summer upwelling, constitutes the northern part of the Eastern North Atlantic Upwelling / Canary System and is connected to the presence of the Azores high-pressure system and the development of northerly alongshore winds (Fiuza, 1983).

Waters Upwelled waters are transported southwards by a jet-like surface current, the Portuguese Coastal Current (PCC), the coastal component of the Portuguese current (PC) that branches of the North Atlantic Current, (Fiuza, 1982, 1983; Fiúza and Macedo, 1982). On the southern/ Algarve coast, upwelling favorable conditions are rare, but western upwelled waters flow around Cape S. Vicente and along the south coast, (Fiuza, 1982, 1983; Fiúza and Macedo, 1982; Sánchez and Relvas, 2003) generating high biological productivity that can spread to its easternmost sector (Cardeira et al., 2013). This eastward flow of cold western upwelled waters is alternated with the propagation of westward flows related to warm water and increased vertical stratification and show a direct relationship between flow velocity and water temperature (Garel et al., 2016; Relvas and Barton, 2002).

In winter, the prevalence of westerly/southwesterly winds leads to the occurrence of a predominantly poleward surface and subsurface current, the Iberian Poleward Current (IPC). It consists of an upper slope/shelf break poleward flow that is a branch of the Azores current, transports saltier and warmer (subtropical) waters (Peliz et al., 2005) and depends most on the intensity of the southerly winds (TelesMachado et al., 2015). Another important feature of the winter circulation over the western margin is the formation of coastal buoyant plumes, characterized by low salinities and temperature lower than the ambient shelf waters (Peliz et al., 2005). Such plumes result from the discharge of freshwater from rivers, which in turn reflects continental precipitation. Precipitation occurs mainly in winter, as a result of the moist carried by the westerly winds into the Peninsula, but has important latitudinal differences, from $500 \mathrm{~mm} /$ year in the southeast to $>3000 \mathrm{~mm} /$ year in the northwestern area (Miranda et al., 2002). As a consequence, buoyant plumes are mainly associated to the major northern Portuguese rivers (Minho, Douro, Mondego) but occur also associated to the Tagus, and can either develop into inshore currents, under typical winter downward conditions, or spread offshore under northerly wind periods (Iglesias et al., 2014; Marta-Almeida et al., 2002; Mendes et al., 2016; Oliveira et al., 2007; Otero et al., 2008).

\section{Material and Methods}

This study compares proxy data from 8 records collected from 5 sites along the inner-shelf of the Iberian Margin (Table 1, Figure 1). Three cores were retrieved in the Northern area and off Vigo

(GeoB11033-1 referred to as Galiza), off the Minho River mouth (Diva09 GC, Diva from now on) and 
Clim. Past Discuss., doi:10.5194/cp-2017-39, 2017

Manuscript under review for journal Clim. Past

Discussion started: 16 March 2017

(c) Author(s) 2017. CC-BY 3.0 License.

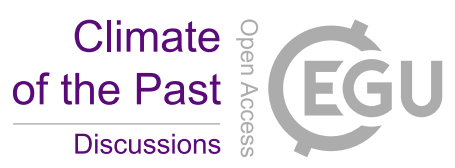

in the Douro sediment patch (PO287-6G, designated as Porto); 4 cores were retrieved in the central western Iberia off the Tagus River mouth (PO26- B PO26G, D13902 and D13882), and 1 core from southern Iberia at Algarve margin (POPEI VC2B). With the exception of the Galiza core, all other sedimentary sequences were collected in the inner shelf, and in areas directly affected by river discharge.

Iron $(\mathrm{Fe})$ content as counts per second (cps) was determined by X-ray fluorescence core scanning for non-destructive semi-quantitative analysis of major elements at MARUM - Bremen University.

Alkenones and higher plant n-alkanes, were determined on $2 \mathrm{~g}$ of homogenized sediment using a Varian gas chromatograph Model 3800 equipped with a septum programmable injector and a flame ionization detector at the DivGM-IPMA laboratory according to the methods described in (Villanueva, 1996; Villanueva and et, 1997; Villanueva and Grimalt, 1997). Analytical precision was $0.5^{\circ} \mathrm{C}$. The concentration of each compound was determined using n-nonadecan-1-ol, n-hexatriacontane and ntetracontane as internal standards. For Sea Surface Temperature (SST) calculation, the global character of the (Müller et al., 1998) calibration determined its selection.

15 Sample preparation procedure for pollen analyses is described in detail at http://www.ephepaleoclimat.com/ephe/Pollen\%20sample\%20preparation.htm and (Naughton et al., 2007). Pollen and spores were counted using a Nikon light microscope at x550 and x1250 (oil immersion) magnification. Pollen identification was done via comparison with the atlases of (Moore et al., 1991); and (Reille, 1992). A minimum of 100 Lycopodium grains, 20 pollen types and 100 pollen grains, excluding the overrepresented Pinus, have been counted (Naughton et al., 2007). Pollen was gathered in two main groups: AP (arboreal pollen) including all trees and shrubs but excluding the overrepresented pine taxa and the semi-desert plants, which groups xerophytic shrubs of semi-desert habitats (Artemisia, Chenopodiaceae, Ephedra);

To reduce individual noise and better evaluate the most robust multi-decadal variability at the regional level, a stack off all the cores was created for SST and n-alkanes original records, without previous alignment. Each core was centered (subtracting each value by the mean) and scaled (dividing the centered columns by its standard deviation). This technique weights high-resolution records more heavily and prevents interpolation across gaps or hiatuses from affecting the stack (Lisiecki and Raymo, 2005).

30 Given that temporal resolution changes along each and every core, a 2 ky stack was attempted for different bin sizes (20 to $50 \mathrm{yr}$ ). Results revealed that main trends were independent of the used size bin (not shown for brevity), but to convey with the most recent compilation works $30 \mathrm{yr}$ bins were used (Ahmed et al., 2013; Luterbacher et al., 2016). Furthermore, in order to investigate possible contrasts between the northern and southern sites, one additional stack was produced just for the northern sites (Galiza, Minho e Porto). To verify any potential effect of the existing hiatus on the Tagus record (Abrantes et al., 2005), as well as any possible bias caused by the Algarve record, stacks were also 
Clim. Past Discuss., doi:10.5194/cp-2017-39, 2017

Manuscript under review for journal Clim. Past

Discussion started: 16 March 2017

(c) Author(s) 2017. CC-BY 3.0 License.

constructed excluding the Tagus record, and excluding the Algarve one. Figure 2 shows a comparison of the calculated stacks for SST, demonstrating that the trends are maintained.

To investigate the existence of periodic signals and potential changes in their amplitude of variation over time, we carried out a continuous transformation of the time series with a Morlet wavelet analysis on each dataset and stack (Torrence and Compo, 1998), after interpolation of the series to regular time steps. Interpolation was done using a cubic splines method and the temporal resolution of the interpolation was established as half of the absolute median difference between every consecutive time span. Data was then detrended using a modified negative exponential curve, as required for the analysis. All statistical analysis was done using the libraries dplR (Bunn et al., 2017) and Akima (Akima and Gebhardt, 2016), from r-project (R Core Team, 2013).

\section{Age model}

Age-depth models of 5 records have been previously published (Table 1).

The Galiza (GeoB11033-1), Minho (DIVA09 GC) and Algarve (POPEI VC2B) age-depth models were constructed based on accelerator mass spectrometry radiocarbon (AMS ${ }^{14} \mathrm{C}$ ) and ${ }^{210} \mathrm{~Pb}$-inferred dates.

${ }^{210} \mathrm{~Pb}$ activity analysis, which provides a method to assess mass accumulation rates, was performed at NIOZ. AMS ${ }^{14} \mathrm{C}$ - accelerator mass spectrometry (AMS) radiocarbon measurements were performed at the Leibniz-Laboratory for Radiometric Dating and Stable Isotope Research, Kiel (Germany), the National Ocean Sciences AMS Facility of the Woods Hole Oceanographic Institution (USA), and Beta Analytic (Table 2).

20 Raw AMS ${ }^{14} \mathrm{C}$ dates were corrected for marine reservoir ages of $400 \mathrm{yr}$ (Abrantes et al., 2005) and converted to calendar ages using INTCAL04 (Reimer et al., 2004). The obtained calendar ages are presented in years Anno Domini, now designated by Common Era (CE - (McKim, 1998).

All age models were interpolated linearly between all accepted ${ }^{14} \mathrm{C}$ dated levels.

\section{Results and Discussion}

Proxy reconstructions are in general, affected by many limitations; from dating uncertainties and coarse temporal resolution, to challenging temporal correlations, or yet in determining the seasonality of the process(es) leading to the generation of each used proxy. However, the signal blender effect of the sediments is also been shown to be an advantage (Hernández et al., 2015).

The sedimentary sequences selected for this study have a high temporal resolution, that is, in order of 2$3 \mathrm{yr}$ in the recent sediments and down to $30 \mathrm{yr}$ in the older part due to a larger sampling interval (Table 1). Furthermore, the measurement of multiple proxies, for Sea Surface Temperature (SST) and on-land Precipitation in the same archive, reduces the difficulties in temporal correlation.

\subsection{Sea Surface Temperature (SST)}


Clim. Past Discuss., doi:10.5194/cp-2017-39, 2017

Manuscript under review for journal Clim. Past

Discussion started: 16 March 2017

(c) Author(s) 2017. CC-BY 3.0 License.

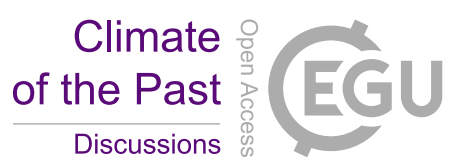

As a proxy for SST we use the alkenone $\mathrm{U}^{\mathrm{k}^{\prime}}{ }_{37}$ derived temperature applying the global calibration of (Müller et al., 1998). A local calibration for the Porto site, via SST data from a $5^{\circ}$ grid provided by the Climatic Research Unit shows the alkenone SST as a Spring / Fall record Abrantes (Abrantes et al., 2011). In order to confirm that indication for other sites, the same exercise was performed, but now using a smaller grid satellite estimated mean annual and seasonal temperatures for the Porto, Lisbon and Algarve sites. As it can be observed in figure 3, at the west coast sites, alkenone production appears associated to the late winter-spring phytoplankton bloom resulting from the nutrient input by the large Douro and Tagus Rivers (Cabeçadas et al., 2003. ; Cabeçadas et al., 2008; Guerreiro et al., 2013). In contrast, the alkenone derived SST measured in the sediments at Algarve (south Iberia), the alkenone derived SST follows the spring/ fall SST that coincide with the annual mean satellite SSTs (Fig. 3), suggesting a minor influence of the smaller and more distant Guadiana River on the site, but a dominant influence of the waters advected from the west coast during the upwelling season, into the local bloom development (Moita, 2001).

Figure 4A displays the alkenone derived SST reconstructions for all the Iberian margin records.

15 Although the differences in the period covered by each record, the temporal resolution of the different cores, and even the different seasons recorded by the SST at distinct sites, all the sites reveal an overall long-term cooling trend from $0 \mathrm{CE}$ up to the beginning of the $20^{\text {th }}$ century. This trend corresponds to the last segment of the $4{ }^{\circ} \mathrm{C}$ decreasing trend reported for the entire Holocene in this region by Rodrigues et al, (Rodrigues et al., 2009), similar to the more recently observed in Europe and worldwide (Ahmed et al., 2013; Luterbacher et al., 2016; McGregor et al., 2015). This general cooling was ascribed to an orbital driven decrease in Northern Hemisphere summer insolation. In Iberia, this long-term sea surface cooling is stronger in the Tagus site $\left(2.5^{\circ} \mathrm{C} / 2 \mathrm{ky}\right)$ than in all other sites $\left(1^{\circ} \mathrm{C} / 2 \mathrm{ky}\right)$. Moreover, SST minima occur off Oporto $\left(14\right.$ to $\left.16^{\circ} \mathrm{C}\right)$ while the warmest temperatures are found in the Algarve inner shelf $\left(17\right.$ to $\left.20^{\circ} \mathrm{C}\right)$. Tagus, Minho and Galiza reconstructions show intermediate values (15 to $18{ }^{\circ} \mathrm{C}$ ). The temperature difference between areas is maintained throughout the last $2 \mathrm{ky}$ but variability shows higher amplitude in the Tagus and Algarve sites $\left(3^{\circ} \mathrm{C}\right)$ compared to the $1.5^{\circ} \mathrm{C}$ observed in the northern sites (Porto, Minho and Galiza).

Both the individual SST records and the SST stack (Fig. 4B) display a secular scale variability comparable with that recorded for Europe and the North Hemisphere (Figure 4C - E); (Luterbacher (Luterbacher et al., 2016; Masson-Delmotte et al., 2013; Moberg et al., 2005). Relatively high SSTs occur during the first 9 centuries encompassing the Roman and Dark Ages (Fig. 4), when SST is slightly higher than the recorded for the $20^{\text {th }}$ century at the Southern sites (Tagus and Algarve; Table 3). Consistent warmth conditions are also recognized at all sites as reflected by the stack between 900 and 1300 CE (Figure 4B), within the timing of the Northern Hemisphere Medieval Warm Period (MWP) also designated by Medieval Climate Anomaly (MCA). Furthermore, the warmest first phase of the MWP from western Iberia records contrast with a coldest phase in southern Iberia (Algarve). The 
Clim. Past Discuss., doi:10.5194/cp-2017-39, 2017

Manuscript under review for journal Clim. Past

Discussion started: 16 March 2017

(c) Author(s) 2017. CC-BY 3.0 License.

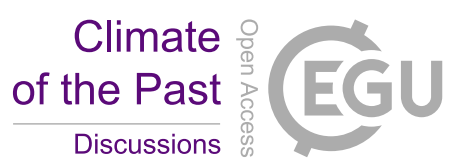

warmest phase of the MWP in western Iberia is in accordance with the findings of (Cunningham et al., 2013) for the NE North Atlantic.

Reconstructed cold conditions in Iberia, with an average $0.5{ }^{\circ} \mathrm{C}$ colder SST in the northern sites and $1.2^{\circ} \mathrm{C}$ in the southern sites, characterize most of the $15^{\text {th }}$ to $18^{\text {th }}$ centuries (Figure $4 \mathrm{~B}$ ). The transition from warm to colder climatic conditions occurs around $1300 \mathrm{CE}$ associated with the Wolf solar minimum (Fig. 4B, G). The coldest SSTs are detected between 1350 and $1850 \mathrm{CE}$, on Iberia during the well-known Little Ice Age (LIA) (Bradley and Jones, 1993), with the most intense cooling episodes related with other solar minima events, and major volcanic forcing (Fig. 4F, G) and separated by intervals of relative warmth (e.g. (Crowley and Unterman, 2013; Solanki et al., 2004; Steinhilber et al., 2012; Turner et al., 2016; Usoskin et al., 2011)).

During the $20^{\text {th }}$ century, the southern records show unusually large decadal scale SST oscillations in the context of the last 2 millennia, in particular after the mid 1970's (Fig. 4A), within the Great Solar Maximum (1940 - 2000 - (Usoskin et al., 2011) and the "greater salinity anomaly" event in the northern Atlantic (Dickson et al., 1988), or yet the higher global temperatures of the last 1.4 ky detected by (Ahmed et al., 2013).

Although the increased amplitude of variability in SST for the last 50 years of record, in particular at the Algarve site, this may result of the effect of a higher resolution and better proxy preservation in the more pristine recent sediments (Calvert and Pedersen, 2007), or, it can also be a reflection of the expected increase of climatic extremes in particular in spring and summer at southwestern Iberia, as a reaction to climate warming (IPCC, 2013a; Miranda et al., 2002).

\subsection{Temperature and Precipitation over western Iberia}

Higher river discharge parallels precipitation patterns (Trigo and DaCamara, 2000), and previous work in the area revealed sediment $\mathrm{Fe}$ content as a good proxy for instrumentally measured river outflow (Abrantes et al., 2009). The new sites lack such data, but given that Fe and lipid compounds synthesized by higher plants, such as $\mathrm{C} 23-\mathrm{C} 33 \mathrm{n}$-alkanes ([n-alc]), show a coherent pattern of variability at both the Tagus and Porto sites (Abrantes et al, 2005b, 2011), a Pearson correlation of 0.47 at $p>0.01$ and $n=250$, and that [n-alc] is available for all sites, we will use this proxy to qualify the intensity of River runoff.

Furthermore, Total Pollen Concentration (TPC), which also reflects the relative quantity of terrestrial material that reaches the marine environment mainly through river discharges, is considered as an independent proxy (Naughton et al., 2007; Naughton et al., 2009). Moreover, pollen production occurs during the spring season and should therefore reflect atmospheric temperature and precipitation during that season (e.g. (Guiot et al., 2009)). However, trees growth is completely dependent on the humidity of the previous winter season (Gouveia et al., 2008). In this work we use the arboreal and the semidesertic groups as proxies for those conditions on land. The arboreal pollen representing a sum of the 
Clim. Past Discuss., doi:10.5194/cp-2017-39, 2017

Manuscript under review for journal Clim. Past

Discussion started: 16 March 2017

(c) Author(s) 2017. CC-BY 3.0 License.

precipitation to grow. The expansion of semi-desert plants (Ephedra, Chenopodiaceae and Artemisia) reflects increasing dry conditions all over the year.

\subsubsection{The $[\mathrm{n}$-alc] record}

The Galiza site shows the lower concentrations of higher plants n-alkanes, between 100 and 700 (ng/g), and the Douro the highest (1000 to 7000 (ng/g), while the Minho, Tagus and Algarve sites concentrations vary between 700 and 4000 (ng/g) (Fig. 5A). That is, in general terms, the present day conditions of higher mean annual precipitation in the northern Portuguese area relatively to its north and south locations, have been maintained at least up to $1700 \mathrm{CE}$, timing at which the northern sites show a clear drop in river flux, and mean values in the Algarve surpass the northern ones (Fig. 5A). Furthermore, while off Porto large n-alkanes concentrations point to intense river discharge with centennial to decadal variability throughout the MWP and most of the LIA, the Lisbon and Algarve records show reduced and less variable river discharges up to $1300 \mathrm{CE}$.

Given the difference in precipitation regime between the north and southern regions, we compare the anomalies of the northern sites stack to the Tejo and Algarve anomalies. Its comparison (Fig. 5B) highlights a similar trend in the Tagus and the Algarve for the first $600 \mathrm{yr}$, time at witch the Algarve anomaly becomes more positive. In the MWP, strong positive deviations occur during the early MWP (1000-1100 CE) in the northern rivers while the Tagus and the Algarve records show negative deviations specially pronounced for the Tagus. Between 1100 and $1700 \mathrm{CE}$ similar river flows variability is observed at all latitudes, with positive anomalies in all records after $1350 \mathrm{CE}$. By $1700 \mathrm{CE}$ the northern rivers turn to negative while the Algarve record reaches its most positive anomalies between 1930 and 1970 CE (Fig. 5A).

Precipitation variability on Iberia, reflected by changes in the quantity of river discharges, can also be estimated from oscillations in the total pollen concentration (TPC) (Naughton et al., 2009). TPC data, although at a very low temporal resolution, is available for 3 locations, Minho, Lisbon and Algarve (Fig. 5C). The TPC data suggest a much larger river discharge during the RP in the Tagus than in the Minho or the Algarve. Although somewhat larger values are also suggested by the Tagus [n-alc] concentrations, the two records are not equivalent. However, the observation of the entire Holocene record off the Tagus core (D13882) (Rodrigues et al., 2009) a clear increase of terrestrial input starts during de RP. During the DA and the MWP riverine input/precipitation is higher at the Minho and Tagus hydrological basins than in the southern Iberia (Algarve) up to $1400 \mathrm{CE}$ when Algarve record rises to values comparable to the Minho. Given the uncertainty associated to proxy records, to substantiate our [n-alc] record of on-land precipitation, our records are compared not only with the Tagus flood reconstructions based on the hydrological basin terraces (Benito et al., 2003); (Benito et al., 2004); (Benito et al., 2005) and the Taravilla Lake sediment record from the headwaters of the Tagus 
Clim. Past Discuss., doi:10.5194/cp-2017-39, 2017

Manuscript under review for journal Clim. Past

Discussion started: 16 March 2017

(c) Author(s) 2017. CC-BY 3.0 License.

Douro and Minho Rivers, and by (Barriendos and Rodrigo, 2006) for most IP basins including the coastal Mediterranean, or yet to daily journals for the most recent flood events of the Guadiana River (Barriendos and Martin-Vide, 1998; Barriendos and Rodrigo, 2006; Cabrita, 2007; Varzeano, 1976) (Table 4). Those intervals are marked on figure 5 and although the age uncertainties, the northern sites stack [n-alc] maxima between 1000 and 1100 AD coincide with reports of major flooding events in both the Douro and Minho (Tullot, 1988). Other periods marked by strong precipitation occur in the MWP between $1180-1200 \mathrm{CE}$, and again in the beginning of LIA, 1450- $1470 \mathrm{CE}$. In the Tagus sites (Lisbon) the record also agrees with Tagus flooding times (1200 - $1280 \mathrm{CE} ; 1950-1980 \mathrm{CE})$. The Algarve site, located $80 \mathrm{~km}$ to the west of the Guadiana River mouth appears to be recording not only at the most recent newspaper's reported flooding events of 1876 and 1979 CE (Cabrita, 2007); (Varzeano, 1976), but also the Atlantic basin flooding events (Benito et al., 2004); (Barriendos and Rodrigo, 2006). The similarity of the independently identified records of storm/flooding periods at the various regions, leads to the conclusion that the maxima in [n-alc] can indeed be attributed to extreme precipitation and flooding conditions.

\subsubsection{The pollen record}

Arboreal and semi-desertic pollen variability at the Minho, Tagus and Algarve sites reflect main forest/climate changes over the last 2000 years (Figure 6). Major forest expansion, revealed by increasing arboreal pollen (AP) percentages, occurred during the RP and the MWP as an expression of the relative warm atmospheric Temperature. In contrast a reduction of the forest cover, revealed by a decrease of AP, is detected during the LIA cooling. Between 1700-1800 CE there is a strong decrease of AP in Algarve and Minho suggesting an abrupt cooling episode in Iberia. After $1800 \mathrm{CE}$ a new increase in AP reflects increasing atmospheric temperatures. The expansion/contraction of semi-desert plants, which reflect continental dryness/moisture, should be recorded by the percent abundance of this group. Although the very modest contribution (up to 8\%), this group's latitudinal comparison show that southern Iberia, including Tagus and Algarve sites actual drier conditions relatively to the North of Iberia has been a constant throughout the last $2 \mathrm{ky}$.

AP variability in western Iberia over the last $2000 \mathrm{yr}$ is similar in their general trends to the NE Spain / Cantabria stalagmite $\mathrm{T}$ anomaly (Fig. 6C) (Martín-Chivelet et al., 2011) and resembles pollen influx/temperature variability at Ria de Vigo (Desprat et al., 2003). As to the observed marked decrease of both groups during the LIA, between 1700 and $1800 \mathrm{CE}$, it is likely to result from the shifting between periods of increased frequency of strong rain events and flooding (Barriendos and MartinVide, 1998) and periods of prolonged drought (Barriendos, 2002; Benito and Hudson, 2010). Furthermore, this interval also coincides with a period of stable $\mathrm{T}$ in $\mathrm{N}$ Spain, and minima in European seasonality and Spring atmospheric temperature in Europe (Fig. 6F. G; (Luterbacher et al., 2004) as 
Clim. Past Discuss., doi:10.5194/cp-2017-39, 2017

Manuscript under review for journal Clim. Past

Discussion started: 16 March 2017

(c) Author(s) 2017. CC-BY 3.0 License.

well as a minimum in winter precipitation (Fig. 6C, I) (Martín-Chivelet et al., 2011; Romero-Viana et al., 2011).

\subsection{Climate Forcing Mechanisms}

The variability of a very dynamic and seasonally distinct oceanographic system, as the one observed along the IP Atlantic margin, has multiple attributes that do not always appear in the same combination and can hamper climate reconstructions at all time-scales. Nevertheless, the use of multiple proxies from a single sediment sequence and the regional anomaly stack of the various sites should allow for the more robust climatic structures to be depicted. Furthermore, a site calibration of our SST proxy (alkenone estimated SST) to satellite derived SST confirms its dependence on the season and process providing the conditions for coccolithophores to bloom, and indicates that while in the west coast it reflects winter SSTs in the Algarve mimics spring-fall SSTs (Figure 3). Although this could be seen as a potential problem for the interpretation of our records, the fact that both the millennial SST trend as the secular variability recorded at all sites is comparable and similar to the North Hemisphere and European records (Figure 4; (Luterbacher et al., 2016; Masson-Delmotte et al., 2013; Moberg et al., 2005)), gives us the confidence to use this difference as an opportunity to disentangle winter from spring-fall conditions in the region.

The Atlantic margin of the IP was relatively warmer from 0-1300 CE, in particular during the RP (0$500 \mathrm{CE})$ and the MWP (900-1300 CE), while SST slightly decreases during the DA (500 -900 CE). At about $1300 \mathrm{CE}$, in particular in the southern IP sites, an important SST decrease marks the transition to a clearly colder LIA that lasts up to $1850 \mathrm{CE}$, even though a transition period is perceived to start at mid $18^{\text {th }}$ century in most records. The transition to modern times / Industrial Era, shows a two step increase in SST, with an initial increase followed by a new and more abrupt rise by mid $20^{\text {th }}$ century particularly evidenced in the spring-fall record of the southernmost site.

In terms of on-land precipitation, the early MWP is a period of extreme precipitation and flooding mainly in northern Iberia, off the Douro River (Porto site). During the LIA, a concerted response of all the rivers related sites, reveals a period of frequent but probably less intense precipitation and, within the age uncertainties, in consonance with the flooding intervals recorded on flooding plains, lakes and documents (e.g. (Barriendos and Martin-Vide, 1998); (Benito et al., 2005); (Cabrita, 2007); (Moreno et al., 2008); (Tullot, 1988); (Varzeano, 1976)). Iberian margin records also show evidences of the wellknown major storms of the $20^{\text {th }}$ century.

According to the compilation of Sánchez-Lopes et al, (2015), the climate of the IP during the last 2 ky has been modulated by the combined effect of two main modes of atmospheric circulation, the NAO and the EA. As such, the warm atmospheric T and higher humidity detected in the $\mathrm{W}$ and $\mathrm{S}$ of the IP during the RP are attributed to a negative NAO and a positive EA, and the more humid N with a W-E humidity gradient observed in the DA are attributed to NAO+ and EA-conditions. The consistent warm 
Clim. Past Discuss., doi:10.5194/cp-2017-39, 2017

Manuscript under review for journal Clim. Past

Discussion started: 16 March 2017

(c) Author(s) 2017. CC-BY 3.0 License.

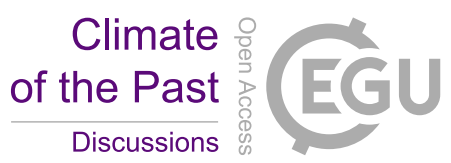

and dry conditions detected during the MWP throughout the IP, are attributed to NAO+ and EA+. On the contrary, NAO- and EA- are considered to explain the cold and wet winters, as well as, the cold summers proposed for the LIA.

Our results do not contradict Sánchez-Lopez conclusions for the RP, the DA and the LIA, but climate specificities, to be discussed below, occur in the early MWP and the Industrial Era, associated to major changes in the solar TSI record (Fig. 4G; (Bard et al., 2007)). Such distinctive features may indicate either a more direct impact of internal oceanic variability on these coastal sites, the effect of the SCAND mode, or yet the interplay of the various atmospheric modes of circulation with oceanic dynamics.

\subsubsection{The MWP phases}

In the early MWP (900 - $1100 \mathrm{CE}$ ), warmer winters are recorded on the west coast while cooler springfalls occur in the Algarve and clustered events of extreme precipitation are registered in the northern IP. On the contrary, the late MWP (1180 - $1280 \mathrm{CE})$ shows relatively cooler winters in the west, warmer spring-fall in the Algarve and no sign of extraordinary winter storms. That is, climacteric conditions that are in contradiction with the expected dry and warm winters as well as warm summers likely to be generated by the prevalence of NAO+ and EA+ modes proposed by (Sánchez-Lopes et al., 2015). Yet, stronger coastal upwelling conditions have also been suggested to explain the productivity record of the southern Tagus site, implying the existence of northerly winds and an active Portuguese Current, that is, a persistent, positive NAO-like state or the frequent occurrence of extreme NAO maxima during the MWP (Abrantes et al, 2005). Furthermore, arboreal pollen indicate relatively warm conditions in both northwestern and southern IP (Fig. 6B), and are in good agreement with atmospheric temperature over NE Spain (Fig. 6C) (Martín-Chivelet et al., 2011) up to the beginning of the LIA, what is likely to reflect similar on-land conditions on both regions. (Marullo et al., 2011) found significant correlations between the AMO and the climate of the Euro-Mediterranean region, mainly in summer and intermediate seasons (spring and fall). Persistent positive NAO conditions during the MWP are also pointed as a source of strong heat transport from the Atlantic and an equally strong north Atlantic current (Yang and Myers, 2007). Furthermore, the Portuguese current is a southward extension of the North Atlantic Current, which in turns flows off the Gulf Stream.

Proxy reconstructions of the Gulf Stream SST and hydrographic variability reveal two periods of warmer SSTs within the general warm waters of the MWP, between $700-1070 \mathrm{CE}$ and again between 1180 and 1280 CE (Fig. 5E) (Saenger et al., 2011). While the general warmth of the MWP is attributed to a more positive NAO like circulation, evidence for lower salinities lead the authors to conclude a northward advection of warm and less saline waters from the tropical Atlantic, in support of fresher tropical Atlantic caused by shifts in the latitudinal position of the ITCZ, and a stronger overturning 
Clim. Past Discuss., doi:10.5194/cp-2017-39, 2017

Manuscript under review for journal Clim. Past

Discussion started: 16 March 2017

(c) Author(s) 2017. CC-BY 3.0 License.

by other Atlantic records (e.g. (Bianchi and McCave, 1999; Boessenkool et al., 2007; Keigwin and Pickart, 1999), and sustained by model simulations that highlight the potential role of the NAO in driving variability in the North Atlantic Sea Surface Temperature (AMO) which is associated with AMOC variability and consequently in the thermohaline circulation (Delworth and Dixon, 2000).

5 Although the existence of salinity anomalies in the northern Atlantic are defended by many model studies as a prerequisite for AMOC intensification (Buckley and Marshall, 2016), some modeling studies emphasize the need for a weakening of the subtropical and subpolar gyres (Häkkinen et al., 2011; Häkkinen et al., 2013), to allow for a greater penetration of warm subtropical waters into the subpolar gyre (e.g (Danabasoglu et al., 2012)). According to (Häkkinen et al., 2011), the mean gyre strength is driven by changes in the wind stress curl that in turn is associated with changes in blocking between Greenland and Western Europe. Considering the modern observations of (Marshall and al, 2001), the Atlantic zero wind stress curl line shifts northward during more positive NAO-like conditions. However, to explain the occurrence of big storms clustered in the early MWP on the northwestern IP (off the Douro River), one has to imply a storm track position southward of the modern path of the westerly winds under $\mathrm{NAO}+$ conditions, to at least $41^{\circ} \mathrm{N}$, a shift that could have been caused by an increase in mid-latitude blocking anticyclones. The SCAND is related to major blocking anticyclones over Scandinavia and has a positive mode associated with above-average precipitation across southern Europe (Comas-Bru and McDermott, 2014; Jerez and Trigo, 2013). Although considered to have a larger influence on the IP in summer than in winter, (Hernández et al., 2015) attribute the interannual winter variability in the northern IP lake Sanabria to the joint action of NAO and SCAND modes, while EA appears to have a weak influence in summer. The regional effect of all three modes of atmospheric circulation on the SST and precipitation at IP, for winter and summer periods, is presented in figure 5 of (Hernández et al., 2015). Bearing in mind the Atlantic coast, besides the evident negative relation observed between NAO and precipitation in winter, EA and SCAND are also positively related to winter precipitation in particular in the northern IP. In summer, there is a slight positive relation of SCAND with precipitation in the north but an important negative effect with temperature in most of IP. Assuming that these modern patterns were maintained during the MWP, one possible explanation for the observed strong precipitation in the north and lower SST in the Algarve during the early MWP may be the effect of a positive SCAND in the early MWP, but negative in late MWP.

To investigate the influence of the Atlantic SST multi-decadal variability of the weather regime over the Atlantic IP region, wavelet analysis was performed on our records (Figs. 7, 8). Both SST and precipitation data series exhibit low frequency variability. Although dominant periods occur within the shaded area the cone of influence, the occurrence of different cycles is taken as an indication of their importance. SST reveals a dominance period centered at $32 \mathrm{yr}$ throughout the north stack (Fig. 7C), two dominant periods centered at 32 and $64 \mathrm{yr}$ throughout the Algarve record (Fig. 7B) and a mix of the two 
Clim. Past Discuss., doi:10.5194/cp-2017-39, 2017

Manuscript under review for journal Clim. Past

Discussion started: 16 March 2017

(c) Author(s) 2017. CC-BY 3.0 License.

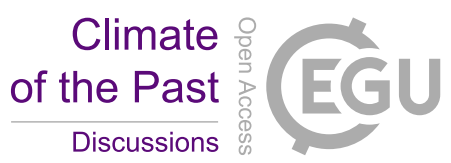

bands when the total stack is considered (Fig. 7A). The precipitation records show the same band of dominance centered at $64 \mathrm{yr}$ in the Algarve record (Fig. 8A), but a dominance centered at $20 \mathrm{yr}$ after \pm $1050 \mathrm{CE}$ for the northern stack (Fig. 8B). That is, a $64 \mathrm{yr}$ period appears for SST both on the west and south coasts as well as for recipitation over the southern Algarve coast. In addition, shorter period processes are found for SST in the Algarve (32 yr), and precipitation in the northern sites (20 yr).

(Stocker and Mysak, 1992), attribute the 38-110 yr cycles found in their model exercise, to natural internal variability. (Frankcombe et al., 2010), propose that the north Atlantic multidecadal variability is dominated by two main time scales, a 20-30 yr associated with the AMOC and so, of ocean internal origin and a 50-70 yr related to the atmospheric exchange between the Atlantic and the Arctic Ocean. (Cunningham et al., 2013), in its NE North Atlantic composite finds 111, 55.6, 40 and $31.3 \mathrm{yr}$ cycles. However, the small amount of variance of the record explained those periods, lead the authors to conclude for a weak influence of ocean internal variability into the NE North Atlantic Climate. More recently, (Buckley and Marshall, 2016), revise the periodicities shown by various instrumental and proxy records, group them into decadal (20 yr) and multidecadal ( $\pm 40-70 \mathrm{yr})$, and present results with statistical significance support for the $70 \mathrm{yr}$ periodicity. Additionally, the authors support (Zhang, 2007) and (Yamamoto and Palter, 2016), in that on decadal and multi-decadal time scale, ocean dynamics does play a role in the European climate variability.

If our wavelet results are interpreted in light of the above-presented information, multi-decadal variability of the North Atlantic dynamics, including the resulting heat transport into Europe, impacts Atlantic IP SST and precipitation in the southern site. Decadal variability, in turn, appears to affect precipitation in the northern sites mainly after $1050 \mathrm{CE}$ and SST in the southern.

\subsubsection{The Industrial Era}

The transition to the Industrial Era, in the northern Porto site, although distinct at $1850 \mathrm{CE}$, starts at 1730-1740 CE (Abrantes et al., 2011) and is accompanied by the return of SSTs to the values observed pre $1300 \mathrm{CE}$. A pattern that coincides with the atmospheric temperature rise detected in NE Spain, Europe and the northern Hemisphere (Luterbacher et al., 2016; Martín-Chivelet et al., 2011; Moberg et al., 2005), as well as with a drought period that mainly affects the Atlantic sector of the Iberian Peninsula (Domínguez-Castro et al., 2010). A second and more marked rise of SST occurs by the mid $20^{\text {th }}$ century $( \pm 1970$ ) being particularly distinct in the southern Algarve site, and in consonance with the second warming phase also observed in the western Mediterranean (Lionello et al., 2006; MartínPuertas et al., 2010).

The transition into the Industrial Era is also marked by a shift in the phytoplankton community and water column stratification over the northern Porto site, which was interpreted by Abrantes et al., (2011), as a response to a reduction in the summer and/or annual upwelling and more frequent 
Clim. Past Discuss., doi:10.5194/cp-2017-39, 2017

Manuscript under review for journal Clim. Past

Discussion started: 16 March 2017

(c) Author(s) 2017. CC-BY 3.0 License.

al., 2005; Gómez-Gesteira M et al., 2008; Pardo et al., 2011; Pérez et al., 2010)). This shift corresponds to an intensified NAO+ phase followed by slightly positive NAO up to $1850 \mathrm{CE}$ (Fig. 4I) (Cook et al., 2002; Luterbacher et al., 2002; Vinther et al., 2003), and is concomitant with a higher coherence between the Porto SST data and the AMO index (Abrantes et al., 2011). On the basis of this information the authors propose a connection between the Iberian coastal upwelling variability and the North Atlantic Ocean's surface and thermohaline circulation at the decadal scale. More recently, (Zampieri et al., 2016), propose that the rapid warming periods of the Northern Hemisphere, including the last one in the ' 90 s, are in great part modulated by shifts in the north Atlantic decadal mode of SST variability (AMO) from negative (cold) to positive (warm phases). A close look to the AMO index records of (Gray et al., 2004) and (Mann et al., 2010) (Fig. 4H), reveals that the two warming steps referred above do indeed occur during warming transitions in the AMO index, supporting the influence of the $\mathrm{N}$ Atlantic SST pattern on the Atlantic IP and its southern area in particular. A connection also defended by (Cisneros et al., 2016) to explain the last 400 yr SST reconstruction of the central-western Mediterranean Sea.

15 The prominent increase in the southern site SST might be explained by the dynamics of the coastal counter-current of the Gulf of Cadiz, were higher SSTs are reached at periods of large-scale northerly winds during the upwelling season (Garel et al., 2016). And a substantial intensification of the upwelling off the Southwestern coast in the last 50 years, particularly noticeable during the peak summer months (July to September) has been defended by (Relvas et al., 2009). Nevertheless, it emerges as a regional imprint of a major reorganization of the oceanic dynamics that is likely to have been initiated in the mid $18^{\text {th }}$ century. Considering the high relevance of such environmental changes to ecosystems, a more in depth discussion of its effect at the regional scale is necessary.

\section{Conclusions}

The combination of SST and terrestrial input/river discharge records from six sites distributed along the Iberian margin, from $36^{\circ}$ to $41^{\circ} \mathrm{N}$ latitude, captures the spatial character of the Iberian margin SST and continental precipitation variability at various time scales through the last $2000 \mathrm{yr}$. Furthermore, a regional anomaly stack for SST and river discharge, constructed from the grouping of individual records' anomalies, provide a meaningful form to understand the role of global/hemispheric vs regional processes.

30 On the long-term, a decreasing trend between $0 \mathrm{CE}$ and the beginning of the $20^{\text {th }}$ century is observed at all latitudes with max amplitude in the southern site.

Within the long term cooling a series of century/decadal scale climate changes are detected by combining information of the different site records. This century/decadal variability follows the overall climatic patterns of the extra-tropical northern Hemisphere and Europe. Warm and wet RP and DA are in accordance with the northeastern Iberian records, as also indicated by the good agreement between 
Clim. Past Discuss., doi:10.5194/cp-2017-39, 2017

Manuscript under review for journal Clim. Past

Discussion started: 16 March 2017

(c) Author(s) 2017. CC-BY 3.0 License.

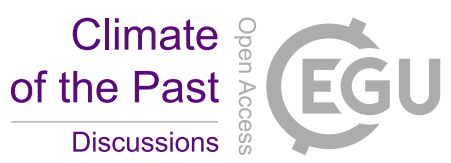

the arboreal vegetation and NE Spain air temperature up to the beginning of the LIA. Colder conditions and frequent but apparently not extreme storms occur during the LIA all along the Atlantic IP concerted with flood plain, lakes and historic documents. The alternation between stormy and drought periods is likely to be the cause for a marked decrease of both arboreal and semi-desertic vegetation at all latitudes during the LIA. However, climate specificities occur in the MWP, mainly in the early MWP and again in the transition from the LIA into the Industrial Era, in both cases, associated to transition periods in solar activity (TSI).

In the MWP, two phases could be distinguished, an early MWP phase marked by warmer winters but cooler spring-falls and extraordinary storms in the northern sites, and a second consistent dry period with warmer spring-falls. To explain the MWP record, we support the propose interplay between the NAO and EA modes of atmospheric circulation, both of which on a positive phase, and suggest a stronger influence of the north Atlantic dynamics on Iberian climate. Furthermore, in the early MWP the flooding record imply a southward shift of the modern storm track under NAO+ conditions, that is, the presence of a high pressure blocking system over northwestern Europe, such as it can be provided by a positive-like mode of the SCAND atmospheric mode of circulation.

The Industrial Era SST rise occurs in two steps, at the end of the LIA (1730-1850), and again in the mid $20^{\text {th }}$ century. At $1800 \mathrm{CE}$ an imprint of oceanic processes becomes apparent in the northern records, supporting a stronger influence of the internal ocean variability into the Atlantic IP climate. This second increase in SST is particularly marked in the southern Algarve site as a regional imprint of a largerscale process that can also reflect the global warming impact that is expected mainly for southern Iberia.

\section{Team list}

\section{Copyright statement}

\section{Code availability}

\section{Data availability}

Data will be archived at PANGEA and link to data will be included on the final version

\section{Appendices}

\section{Author contribution}

Abrantes, F - PI of the various projects that funded all the data combined in this paper, has the idea and wrote the paper;

Rodrigues, T- Responsible for the biomarkers analysis in all cores; 
Clim. Past Discuss., doi:10.5194/cp-2017-39, 2017

Manuscript under review for journal Clim. Past

Discussion started: 16 March 2017

(c) Author(s) 2017. CC-BY 3.0 License.

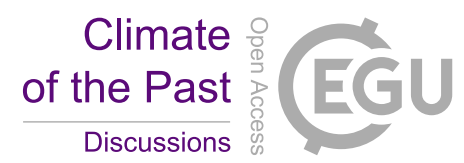

Rufino, M - Statistical data analysis;

Naughton' $\mathrm{F}$ - Responsible for the pollen analysis;

Salgueiro, E - Data of GeoB11033-1 core;

Oliveira, D - Pollen analysis of the DIVA and POPEI cores;

5 Domingues, $\mathrm{S}$ - Pollen analysis for the Tagus site D13882 core;

Costa, A. - Age model for GeoB11033-1;

Oliveira, P - Provided the satellite SST data;

Drago, T - Provided the Algarve core (POPEI);

Mil-Homens, M - Recovered the DIVA core;

10

\section{Acknowledgments}

The authors express their gratitude to the captain, crew and participants of the cruises Discovery 249, Poseidon PALEO I, GALIOMAR P34, and B/O Mytilus DIVA09 for their contribution during the retrieval of the various cores used in this study. Thanks are due in particular to Guilhermo F. Pedraz and the Departamento de Geociencias Marinas y Ordenación del Territorio (Universidade de Vigo) for allowing the recovery of the DIVA core on their DIVA09 cruise.

Funding was provided by projects INGMAR (FCT ARIPIPI Program -Support for State Labs Development), HOLSMEER (EVK2-CT-2000-00060), CLIMHOL (PTDC/AAC-CLI/100157/2008), MIÑO-MINHO (0234_NATURA_MM_1_E), POPEI (PDCT/MAR/55618/2004), CALIBERIA

(PTDC/MAR/102045/2008 from FCT and COMPETE/FEDER -FCOMP-01-0124-FEDER-010599), CIIMAR (20132017 CIMAR), CCMAR (Associated Lab PEstC/ MAR/LA0015/2013); felowships to Filipa Naughton (SFRH / BPD / 36615 / 2007), Teresa Rodrigues (SFRH/BPD/66025/2009), Emília Salgueiro (Ref. SFRH / BPD / 26525 / 2006 \& SFRH / BPD /111433 / 2015). Marta Rufino was funded by contrato ciência 2007 and by a post- doctoral grant of IPMA, within the EU project SAFI (FP7-

25 SPACE-2013-1, grant agreement n8 607155). Finally we thank A. Inês, D. Ferreira and C. Monteiro for their help and support with the laboratory analysis. This is a contribution to the PAGES $2 \mathrm{k}$ Network. Past Global Changes (PAGES) is supported by the US National Science Foundations and Swiss Academy of Sciences. 
Clim. Past Discuss., doi:10.5194/cp-2017-39, 2017

Manuscript under review for journal Clim. Past

Discussion started: 16 March 2017

(c) Author(s) 2017. CC-BY 3.0 License.

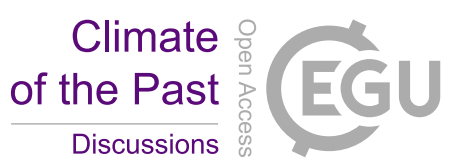

\section{List of Tables and Figures}

Table 1 - Geographic location, water depth, sampling cruise, sedimentation rate (SR) and age model origin for the eight studied cores.

5

Table 2 - Results of 14C accelerator mass spectrometry dating (means \pm SE) of the cores GeoB11033-1 (Galiza), DIVA 09CG (Minho) and POPEI VC2B (Algarve). Ages were reservoir corrected by $400 \mathrm{yr}$ (years before present, yr BP) and converted into calendar years (AD/CE).

Table 3 -SST mean during major climatic episodes along Atlantic margin of the Iberian Peninsula.

Existing sediment hiatus likely affected estimated value. Shades of blue and pink highlight respectively colder and warmer periods.

Table 4 - Compilation of flooding and drought events on the western Iberian Peninsula, according to published information.

Figure 1 -Cores location over Iberian Margin bathymetry. Geoß11033-1 / Galiza in orange, DIVA09 GC / Minho in magenta, PO287-6B, -6G / Porto (Douro Mud Belt) in blue, PO287-26B, -26G, D130902, D13882 Lisbon (Tagus Mud Belt) in green, and POPEI VC2B/ Algarve in red. The color selected for each region will be applied in all figures.

Figure 2 - Comparison of SST stacks constructed using all the cores (total - black), without the Tagus cores (effect of existing hiatus - green), without the Popei record (effect of different coccolithophores generating process - red) and considering only the northern sites (Galiza, Minho and Porto - blue)

Figure 3 - Comparison of alkenone-derived sea surface temperature (SST - black diamonds) measured in cores PO287-6B, PO287-26B and POPEI with annual, seasonal average, NAO winter (djfm) and upwelling season (mjjas) satellite derived SST at the three sites location.

30 Figure 4 - Comparison of SST along the last 2,000 years at sites Galiza (magenta), Minho (orange), Porto (blue), Lisbon (green) and Algarve (red) (A); SST stack constructed from all Iberian margin records (B); northern Hemisphere annual mean atmospheric temperature anomaly (Moberg et al., 2005) (C); northern Spain atmospheric temperature anomaly (Martín-Chivelet et al., 2011) (D); European spring-fall atmospheric temperature anomaly (Luterbacher et al., 2016) (E); vulcanic activity as aerosol optical depth (Crowley and Unterman, 2013) (F); radionuclide-derived total solar irradiance (TSI) (Bard et al., 2007) and ${ }^{14} \mathrm{C}$ estimated production (Marchal, 2005) (G); northern Atlantic Ocean SST anomaly, 
Clim. Past Discuss., doi:10.5194/cp-2017-39, 2017

Manuscript under review for journal Clim. Past

Discussion started: 16 March 2017

(c) Author(s) 2017. CC-BY 3.0 License.

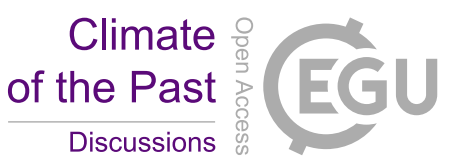

AMO index (gray, (Mann et al., 2010) and (black, Gray et al., 2004) (H); NAO index (Luterbacher et al., 2002) and (Trouet et al., 2009) (I). Light grey band marks the Roman Period (RP), the pink band marks the Medieval Warm Period (MWP/MCA); the blue band marks the Little Ice Age (LIA).

5 Figure $5-[\mathrm{n}$-alc] variability along the last millennium and at the 5 different sites of the Iberian Atlantic margin (A); the [n-alc] stack anomaly of the north sites, Tagus and Algarve (B); total pollen concentration (\# pollen grains $/ \mathrm{cm}^{3}$ sediment) (C); SST stack anomaly (D); SST NW Atlantic cores KNR140-2-59GGC and CH07-98-MC22 (Saenger et al., 2011) (E); instrumental NAO index (black line), Luterbacher reconstruction (black line; Luterbacher et al. 2002), Cook reconstruction (green line; (Cook et al., 2002) and (gray line; Trouet et al, 2009) (F); Radionuclide-derived total solar irradiance (TSI) (Bard et al., 2007) (G). Grey bands mark the periods of Atlantic flooding as listed in Table 4.

Figure 6 - Variability of semi-desert plants percent percentages along the 2,000 yr record of cores Diva, Tejo and Popei (A); arboreal species percent abundance (B); northern Spain atmospheric temperature anomaly (Martín-Chivelet et al., 2011) (C); European spring-fall atmospheric temperature anomaly (Luterbarher et al., 2016) (D); Spring Precipitation Central Europe (Büntgen et al., 2011) (E): European Seasonality and Spring AT (Luterbacher et al., 2004) (F, G); may-august Precipitation (Touchan et al., 2005) (H); winter (djfm) Precipitation (Romero-Viana et al., 2011) (I).

Figure 7 - The continuous wavelet power spectrum of the SST STACK (A); the Algarve SST record (B); and the north SST STACK (C). The thick black contour designates the 95\% confidence level and the lighter shaded area represents the cone of influence (COI) where edge effects might distort the results.

Figure 8 - The continuous wavelet power spectrum of the Algarve [n-alc] record (A) and the north [nalc] STACK (B). The thick black contour designates the $95 \%$ confidence level and the lighter shaded area represents the cone of influence (COI) where edge effects might distort the results.

\section{References}

Abrantes, F., Lebreiro, S., Rodrigues, T., Gil, I., Bartels-Jónsdóttir, H., Oliveira, P., Kissel, C., and Grimalt, J. O.: Shallow-marine sediment cores record climate variability and earthquake activity off Lisbon (Portugal) for the last 2,000 years., Quaternary Science Reviews, doi:

10.1016/j.quascirev.2004.04.009, 2005. 2005.

Abrantes, F., Lopes, C., Rodrigues, T., Gil, I., Witt, L., Grimalt, J., and Harris, J.: Proxy calibration to instrumental data set: Implications 
Clim. Past Discuss., doi:10.5194/cp-2017-39, 2017

Manuscript under review for journal Clim. Past

Discussion started: 16 March 2017

(c) Author(s) 2017. CC-BY 3.0 License.

Abrantes, F., Rodrigues, T., Montanari, B., Santos, C., Witt, L., Lopes, C., and Voelker, A. H. L.:

Climate of the last millennium at the southern pole of the North Atlantic Oscillation: an inner-shelf sediment record of flooding and upwelling, Climate Research, 48, 261-280, 2011.

Ahmed, M., Anchukaitis, K. J., Asrat, A., Borgaonkar, H. P., Braida, M., Buckley, B. M., Buntgen, U.,

5 Chase, B. M., Christie, D. A., Cook, E. R., Curran, M. A. J., Diaz, H. F., Esper, J., Fan, Z.-X., Gaire, N. P., Ge, Q., Gergis, J., Gonzalez-Rouco, J. F., Goosse, H., Grab, S. W., Graham, N., Graham, R., Grosjean, M., Hanhijarvi, S. T., Kaufman, D. S., Kiefer, T., Kimura, K., Korhola, A. A., Krusic, P. J., Lara, A., Lezine, A.-M., Ljungqvist, F. C., Lorrey, A. M., Luterbacher, J., Masson-Delmotte, V., McCarroll, D., McConnell, J. R., McKay, N. P., Morales, M. S., Moy, A. D., Mulvaney, R., Mundo, I. A., Nakatsuka, T., Nash, D. J., Neukom, R., Nicholson, S. E., Oerter, H., Palmer, J. G., Phipps, S. J., Prieto, M. R., Rivera, A., Sano, M., Severi, M., Shanahan, T. M., Shao, X., Shi, F., Sigl, M., Smerdon, J. E., Solomina, O. N., Steig, E. J., Stenni, B., Thamban, M., Trouet, V., Turney, C. S. M., Umer, M., van Ommen, T., Verschuren, D., Viau, A. E., Villalba, R., Vinther, B. M., von Gunten, L., Wagner, S., Wahl, E. R., Wanner, H., Werner, J. P., White, J. W. C., Yasue, K., and Zorita, E.: Continental-scale temperature variability during the past two millennia, Nature Geosci, advance online publication, 2013.

Akima, H. and Gebhardt, A.: akima: Interpolation of Irregularly and Regularly Spaced Data. R package version 0.6-2. 2016.

Alvarez, I., Gomez-Gesteira, M., deCastro, M., and Prego, R.: Variation in upwelling intensity along the NorthWest Iberian Peninsula (Galicia), Journal of Atmospheric \& Ocean Science, 10, 309-324, 2005.

Bard, E., Raisbeck, G., Yiou, F., and Jouzel, J.: Comment on "Solar activity during the last $1000 \mathrm{yr}$ inferred from radionuclide records by Muscheler et al. (2007). Quaternary Science Reviews, 26, 2301-2308, 2007.

Barriendos, M.: Los riesgos climáticos a través de la historia: avances en el estudio de episodios atmosféricos extraordinarios. In: Riesgos naturales, Ayala-Carcedo, F. J. and Olcina, J. (Eds.), Ariel, Barcelona, 2002.

Barriendos, M. and Martin-Vide, J.: Secular climatic oscillations as indicated by catastrophic floods in the Spanish Mediterranean coastland area. , Climate Change 38, 473-491, 1998.

Barriendos, M. and Rodrigo, F. S.: Study of historical flood events on Spanish rivers using documentary data, Hydrological Sciences Journal, 51, 765-783, 2006.

Benito, G., Barriendos, M., Llasat, M. C., Machado, M. J., and Thorndycraft, V. R.: Impacts on natural hazards of climatic origin. A.Flood risk. In: Preliminary Evaluation of the Impacts of Climate Change in Spain., Moreno, J. M. (Ed.), Ministerio de Medio Ambiente, Madrid, 2005.

Benito, G., Díez-Herrero, A., and Fernández de Villalta, M.: Flood Response to Solar Activity in the

Tagus Basin (Central Spain) over the Last Millennium, Climatic Change, 66, 27-28, 2004. 
Clim. Past Discuss., doi:10.5194/cp-2017-39, 2017

Manuscript under review for journal Clim. Past

Discussion started: 16 March 2017

(c) Author(s) 2017. CC-BY 3.0 License.

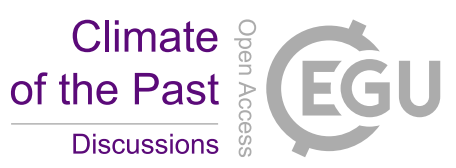

Benito, G. and Hudson, P.: Flood hazards: The context of fluvial Geomorphology. . . In:

Geomorphological Hazards and Disaster Prevention, Alcántara-Ayala, I. and Goudie, A. (Eds.),

Cambridge University Press 2010.

Benito, G., Sopeña, A., Sánchez-Moya, Y., Machado, M. a. J., and Pérez-González, A.: Palaeoflood

5 record of the Tagus River (Central Spain) during the Late Pleistocene and Holocene, Quaternary

Science Reviews, 22, 1737-1756, 2003.

Bianchi, G. and McCave, I.: Holocene periodicity in North Atlantic climate and deep-ocean flow south of Iceland, Nature, 397, 515-517, 1999.

Boessenkool, K. P., I.R. Hall, H. Elderfield, and Yashayaev, I.: North Atlantic climate and deep-ocean

10 flow speed changes during the last 230 years.

, Geophys. Res. Lett., 34, 2007.

Bradley, R. S. and Jones, P. D.: Little Ice Age' summer temperature variations: their nature and relevance to recent global warming trends, The Holocene, 3, 367-376, 1993.

Buckley, M. W. and Marshall, J.: Observations, inferences, and mechanisms of the Atlantic

Meridional Overturning Circulation: A review, Reviews of Geophysics, 54, 5-63, 2016.

Bunn, A., Korpela, M., Biondi, F., Campelo, F., Mérian, P., Qeadan, F., and Zang, C.: dplR:

Dendrochronology Program Library in R. R package version 1.6.5., 2017.

Büntgen, U., Tegel, W., Nicolussi, K., McCormick, M., Frank, D., Trouet, V., Kaplan, J. O., Herzig, F., Heussner, K.-U., Wanner, H., Luterbacher, J., and Esper, J.: 2500 Years of European Climate

Variability and Human Susceptibility, Science, 331, 578, 2011.

Cabeçadas, G., Brogueira, M. J., Nogueira, M., Cabeçadas, L., Cavaco, H., and Nogueira, P.: Coastal phytoplankton productivity associated with different stability and nutrient patterns. , Nice, France2003. , EAE-A-09277.

Cabeçadas, G., Brogueira, M. J., T. Coutinho, and Oliveira, A. P.: Impact of hydrodynamics on the ecology of Douro coastal waters, EGU General Assembly 2008, Viena, 2008.

Cabrita, A. N.: A Cheia Grande no Guadiana, 7 de Dezembro de 1876. In: Eventos Meteorológicos, Estremoz, 2007.

Calvert, S. E. and Pedersen, T. F.: Chapter Fourteen Elemental Proxies for Palaeoclimatic and Palaeoceanographic Variability in Marine Sediments: Interpretation and Application. In:

Developments in Marine Geology, Claude, H. M. and Anne De, V. (Eds.), Elsevier, 2007.

Cardeira, S., Rita, F., Relvas, P., and Cravo, A.: Chlorophyll a and chemical signatures during an upwelling event off the South Portuguese coast (SW Iberia), Continental Shelf Research, 52, 133 149, 2013.

Cisneros, M., Cacho, I., Frigola, J., Canals, M., Masqué, P., Martrat, B., Casado, M., Grimalt, J. O., Pena,

L. D., Margaritelli, G., and Lirer, F.: Sea surface temperature variability in the central-western 
Clim. Past Discuss., doi:10.5194/cp-2017-39, 2017

Manuscript under review for journal Clim. Past

Discussion started: 16 March 2017

(c) Author(s) 2017. CC-BY 3.0 License.

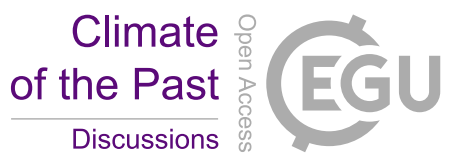

Mediterranean Sea during the last 2700 years: a multi-proxy and multi-record approach, Clim.

Past, 12, 849-869, 2016.

Climate, E.: ESPON CLIMATE - Climate Change and Territorial Effects on Regions and Local Economies in Europe. Applied Research 2013/1/4. Draft Final Report | Version 25/2/2011., TU

5 Dortmund University, Germany., 2011.

Comas-Bru, L. and McDermott, F.: Impacts of the EA and SCA patterns on the European twentieth century NAO-winter climate relationship, Quarterly Journal of the Royal Meteorological Society, 140, 354-363, 2014.

Cook, E., D'Arrigo RD, and ME, M.: A well-verified, multiproxy reconstruction of the winter North Atlantic Oscillation index since A. D. 400, J. Clim., 15, 1754-1764, 2002.

Cook, E. R., Esper, J., and D'Arrigo, R. D.: Extra-tropical Northern Hemisphere land temperature variability over the past 1000 years, Quaternary Science Reviews, 23, 2063-2074, 2004.

Crowley, J. and Unterman, M. B.: Technical details concerning development of a 1200 -yr proxy index for global volcanism, Crowley2013AOD-Reff, 5, 187-197, 2013.

15 Cunningham, L. K., Austin, W. E. N., Knudsen, K. L., Eiríksson, J., Scourse, J. D., Wanamaker, A. D., Butler, P. G., Cage, A. G., Richter, T., Husum, K., Hald, M., Andersson, C., Zorita, E., Linderholm, H. W., Gunnarson, B. E., Sicre, M.-A., Sejrup, H. P., Jiang, H., and Wilson, R. J. S.: Reconstructions of surface ocean conditions from the northeast Atlantic and Nordic seas during the last millennium, The Holocene, 23, 921-935, 2013. Danabasoglu, G., Yeager, S. G., Kwon, Y.-O., Tribbia, J. J., Phillips, A. S., and Hurrell, J. W.: Variability of the Atlantic Meridional Overturning Circulation in CCSM4, Journal of Climate, 25, 5153-5172, 2012.

Delworth, T. L. and Dixon, K. W.: Implications of the recent trend in the Arctic/North Atlantic Oscillation for the North Atlantic thermohaline circulation, J. Clim., 13, 3721-3727, 2000.

Desprat, S., Sánchez Goñi, M. a. F., and Loutre, M.-F.: Revealing climatic variability of the last three millennia in northwestern Iberia using pollen influx data, Earth and Planetary Science Letters, 213, 63-78, 2003.

Dickson, R. R., Meincke, J., Malmberg, S.-A., and Lee, A. J.: The "great salinity anomaly" in the Northern North Atlantic 1968-1982, Progress in Oceanography, 20, 103-151, 1988.

Domínguez-Castro, F., García-Herrera, R., Ribera, P., and Barriendos, M.: A shift in the spatial pattern of Iberian droughts during the 17th century, Clim. Past, 6, 553-563, 2010.

Esper, J., Cook, E. R., and Schweingruber, f. H.: Low-Frequency Signals in Long Tre-Ring Chronologies for Reconstructing Past Temperature, Science, 295, 2250-2253, 2002. 
Clim. Past Discuss., doi:10.5194/cp-2017-39, 2017

Manuscript under review for journal Clim. Past

Discussion started: 16 March 2017

(c) Author(s) 2017. CC-BY 3.0 License.

Fernandez-Donado, L., Gonzalez-Rouco, J. F., Raible, C. C., Ammann, C. M., Barriopedro, D., GarcíaBustamante, E., Jungclaus, J. H., Lorenz, S. J., Luterbacher, J., Phipps, S. J., Servonnat, J.,

Swingedouw, D., Tett, S. F. B., Wagner, S., Yiou, P., and Zorita, E.: Large-scale temperature response to external forcing in simulations and reconstructions of the last millennium, Climate of the Past,

5 9, 293-421, 2013.

Fiuza, A.: The Portuguese Coastal Upwelling, Lisbon1982, 45-71.

Fiuza, A.: Upwelling patterns off Portugal. In: Coastal Upwelling its sediment record., Suess, E. and Thiede, J. (Eds.), Plenum, New York, 1983.

Fiúza, A. and Macedo, M. E.: Climatological space and time variation of the Portuguese coastal upwelling, Oceanologica Acta, 5, 31-40, 1982.

Fiuza, A. A. and Frouin, T. B. R.: Observations of a Warm Oceanic Current Flowing Northward along the Coasts Of Potugal and Spain During Nov-Dec 1983, Eos, Transactions, American Geophysical Union, 67, 1054, 1986.

Frankcombe, L. M., Heydt, A. v. d., and Dijkstra, H. A.: North Atlantic Multidecadal Climate

15 Variability: An Investigation of Dominant Time Scales and Processes, Journal of Climate, 23, 36163638, 2010.

Garel, E., Laiz, I., Drago, T., and Relvas, P.: Characterisation of coastal counter-currents on the inner shelf of the Gulf of Cadiz, Journal of Marine Systems, 155, 19-34, 2016.

Giorgi, F.: Climate change hot-spots, Geophysical Research Letters, 33, n/a-n/a, 2006.

Gómez-Gesteira M, deCastro M, A. I., and JL, G.-G.: Coastal sea surface temperature warming trend along the continental part of the Atlantic Arc (1985-2005). J Geophys Res, 113, 2008.

Gouveia, C., Trigo, R. M., DaCamara, C. C., Libonati, R., and Pereira, J. M. C.: The North Atlantic Oscillation and European vegetation dynamics., Int. J. Climatol, 28, 2008.

Gray, S. T., Graumlich, L. J., Betancourt, J. L., and Pederson, G. T.: A tree-ring based reconstruction of the Atlantic Multidecadal Oscillation since 1567 A.D., GEOPHYSICAL RESEARCH LETTERS, 31, L12205, doi:12210.11029/12004GL019932, 2004.

Guerreiro, C., Oliveira, A., de Stigter, H., Cachão, M., Sá, C., Borges, C., Cros, L., Santos, A., Fortuño, J.M., and Rodrigues, A.: Late winter coccolithophore bloom off central Portugal in response to river discharge and upwelling, Continental Shelf Research, 59, 65-83, 2013.

Guiot, J., Wu HB, Garreta V, Hatté C, and M, M.: A few prospective ideas on climate reconstruction: from a statistical single proxy approach towards a multi-proxy and dynamical approach, Climate of the Past 2009. 5:571-583, 2009.

Häkkinen, S., Rhines, P. B., and Worthen, D. L.: Atmospheric blocking and Atlantic multidecadal ocean variability, Science, 334, 655-659, 2011. 
Clim. Past Discuss., doi:10.5194/cp-2017-39, 2017

Manuscript under review for journal Clim. Past

Discussion started: 16 March 2017

(c) Author(s) 2017. CC-BY 3.0 License.

Häkkinen, S., Rhines, P. B., and Worthen, D. L.: Northern North Atlantic sea surface height and ocean heat content variability

, J. Geophys. Res., 118, 3670-3678, 2013.

Hegerl, G. C., Crowley, T. J., Hyde, W. T., and Frame, D. J.: Climate sensitivity constrained by

5 temperature reconstructions over the past seven centuries, Nature, 440, 1029-1032, 2006.

Hernández, A., Trigo, R. M., Pla-Rabes, S., Valero-Garcés, B. L., Jerez, S., Rico-Herrero, M., Vega, J. C., Jambrina-Enríquez, M., and Giralt, S.: Sensitivity of two Iberian lakes to North Atlantic atmospheric circulation modes, Climate Dynamics, 45, 3403-3417, 2015.

Hurrell, J.: Decadal trends in the North Atlantic Oscillation - regional temperatures and precipitation., Science, 269, 679, 1995.

Iglesias, I., Avilez-Valente, P., Couvelard, X., and Caldeira, R.: Geostrophic influence in the River Douro plume: a climatological

study, Porto2014, 75-80.

IPCC: Annex II: Climate System Scenario Tables In: Climate Change 2013: The Physical Science

Basis. Contribution of Working Group I to the Fifth Assessment Report of the Intergovernmental

Panel on Climate Change, Stocker, T. F., Qin, D., Plattner, G.-K., Tignor, M., Allen, S. K., Boschung, J., Nauels, A., Xia, Y., Bex, V., and Midgley, P. M. (Eds.), Cambridge University Press, Cambridge, United Kingdom and New York, NY, USA, 2013a.

IPCC: Climate Change 2013: The Physical Science Basis. Contribution of Working Group I to the Fifth Assessment Report of the Intergovernmental Panel on Climate Change, Cambridge University Press, Cambridge, United Kingdom and New York, NY, USA, 2013b.

Jambrina-Enríquez, M., Sachse, D., and Valero-Garcés, B. L.: A deglaciation and Holocene biomarker-based reconstruction of climate and environmental variability in NW Iberian Peninsula: the Sanabria Lake sequence, Journal of Paleolimnology, 56, 49-66, 2016.

Jerez, S. and Trigo, R. M.: Time-scale and extent at which large-scale circulation modes determine the wind and solar potential in the Iberian Peninsula, Environmental Research Letters, 8, 044035, 2013.

Jones, P. D., Osborn, T. J., and Briffa, K. R.: The Evolution of Climate Over the Last Millenium., Science, 292, 662-667, 2001.

Keigwin, L. and Pickart, R.: Slope Water Current over the Laurentian Fan on Interannual to Millenial Time Scales., Science, 286, 520-523, 1999.

Lebreiro, S. M., Francés, G., Abrantes, F. F. G., Diz, P., Bartels-Jónsdóttir, H. B., Stroynowski, Z. N., Gil, I. M., Pena, L. D., Rodrigues, T., Jones, P. D., Nombela, M. A., Alejo, I., Briffa, K. R., Harris, I., and Grimalt, J. O.: Climate change and coastal hydrographic response along the Atlantic Iberian margin 
Clim. Past Discuss., doi:10.5194/cp-2017-39, 2017

Manuscript under review for journal Clim. Past

Discussion started: 16 March 2017

(c) Author(s) 2017. CC-BY 3.0 License.

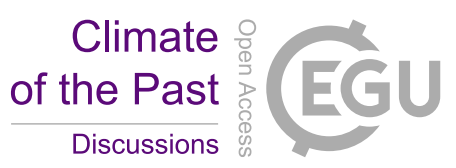

(Tagus Prodelta and Muros Ría) during the last two millennia, The Holocene, 16, 1003-1015, 2006.

Lionello, P., Malanott-Rizzoli, R., Boscolo, R., Alpert, P., Artale, V., Li, L., Luterbacher, J., May, W., Trigo, R., Tsimplis, M., Ulbrich, U., and Xoplaki, E. T.: The Mediterranean climate: An overview of

5 the main characteristics and issues. In: Mediterranean Climate Variability (MedClivar), Elsevier, Amsterdam, 2006.

Lisiecki, L. E. and Raymo, M. E.: A Pliocene-Pleistocene stack of 57 globally distributed benthic D180 records, Paleoceanography, 20, 2005.

Luterbacher, J., Dietrich, D., Xoplaki, E., Grosjean, M., and Wanner, H.: European Seasonal and

10 Annual Temperature Variability, Trends, and Extremes Since 1500, Science, 303, DOI: 10.1126/science.1093877, 2004.

Luterbacher, J., Werner, J. P., Smerdon, J. E., Fernández-Donado, L., González-Rouco, F. J., Barriopedro, D., Ljungqvist, F. C., Büntgen, U., Zorita, E., Wagner, S., Esper, J., McCarroll, D., Toreti, A., Frank, D., Jungclaus, J. H., Barriendos, M., Bertolin, C., Bothe, O., Brázdil, R., Camuffo, D.,

15 Dobrovolný, P., Gagen, M., García-Bustamante, E., Ge, Q., Gómez-Navarro, J. J., Guiot, J., Hao, Z., Hegerl, G. C., Holmgren, K., Klimenko, V. V., Martín-Chivelet, J., Pfister, C., Roberts, N., Schindler, A., Schurer, A., Solomina, O., Gunten, L. v., Wahl, E., Wanner, H., Wetter, O., Xoplaki, E., Yuan, N., Zanchettin, D., Zhang, H., and Zerefos, C.: European summer temperatures since Roman times, Environmental Research Letters, 11, $024001,2016$.

20 Luterbacher, J., Xoplaki, E., Dietrich, D., Jones, P. D., Davies, T. D., Portis, D., Gonzalez-Rouco, J. F., von Storch, H., Gyalistras, D., Casty, C., and Wanner, H.: Extending North Atlantic Oscillation Reconstructions Back to 1500, Atmospheric Science Letters, 2, 114-124, 2002.

Mann, M. E., Zhang, Z., Rutherford, S., Bradley, R. S., Hughes, M. K., Shindell, D., Ammann, C., Faluvegi, G., and Ni., F.: Global Signatures and Dynamical Origins of the Little Ice Age and Medieval Climate Anomaly, Science, 326, 1256-1260, 2010.

Marchal, 0.: Optimal estimation of atmospheric 14C production over the Holocene: paleoclimate implications, Climate Dynamics, 24, 71-88, 2005.

Marshall, J. and al, e.: North Atlantic climate variability: Phenomena, impacts and Mechanisms, International Journal of Climatology, 21, 1863-1898, 2001.

Marta-Almeida, M., Dubert, J., and Peliz, Á.: Simulations of extreme shelf current along the North-Western Iberian Shelf forced by wind and river runoff. , Valencia, Spain2002, 1555-1559.

Martín-Chivelet, J., Muñoz-García, M. B., Edwards, R. L., Turrero, M. J., and Ortega, A. I.: Land surface temperature changes in Northern Iberia since $4000 \mathrm{yr} B P$, based on $\delta 13 \mathrm{C}$ of speleothems, Global and Planetary Change, 77, 1-12, 2011. 
Clim. Past Discuss., doi:10.5194/cp-2017-39, 2017

Manuscript under review for journal Clim. Past

Discussion started: 16 March 2017

(c) Author(s) 2017. CC-BY 3.0 License.

Martín-Puertas, C., Jiménez-Espejo, F., Martínez-Ruiz, F., Nieto-Moreno, V., Rodrigo, M., Mata, M. P., and Valero-Garcés, B. L.: Late Holocene climate variability in the southwestern Mediterranean region: an integrated marine and terrestrial geochemical approach, Clim. Past, 6, 807-816, 2010. Marullo, S., Artale, V., and Santoleri, R.: The SST Multidecadal Variability in the Atlantic-

5 Mediterranean Region and Its Relation to AMO, Journal of Climate, 24, 4385-4401, 2011. Masson-Delmotte, V., Schulz, M., Abe-Ouchi, A., Beer, J., Ganopolski, A., González Rouco, J. F., Jansen, E., Lambeck, K., Luterbacher, J., Naish, T., Osborn, T., Otto-Bliesner, B., Quinn, T., Ramesh, R., Rojas, M., Shao, X., and Timmermann, A.: Information from Paleoclimate Archives. In: Climate Change 2013: The Physical Science Basis. Contribution of Working group I to the Fifth Assessment Report of the Intergovernmental Panel on Climate Change, F., S. T., Qin, D., Platnner, G.-H., Tignor, M., Allen, S. K., Boschung, J., Nauels, A., Xia, Y., Bex, V., and Midgley, P. M. (Eds.), Cambridge University Press, Cambridge, United Kingdom and New York, NY, USA, 2013.

McGregor, H. V., Evans, M. N., Goosse, H., Leduc, G., Martrat, B., Addison, J. A., Mortyn, P. G., Oppo, D. W., Seidenkrantz, M.-S., Sicre, M.-A., Phipps, S. J., Selvaraj, K., Thirumalai, K., Filipsson, H. L., and

Ersek, V.: Robust global ocean cooling trend for the pre-industrial Common Era, Nature Geosci, 8, 671-677, 2015.

McKim, D. K.: Common Era entry, Westminster John Knox Press, Louisville, Kentucky, 1998. Mendes, R., Sousa, M. C., deCastro, M., Gómez-Gesteira, M., and Dias, J. M.: New insights into the Western Iberian Buoyant Plume: Interaction between the Douro and Minho River plumes under winter conditions, Progress in Oceanography, 141, 30-43, 2016.

Miranda, P., M.A., Coelho, F. E. S., Tomé, A. R., Valente, M. A., Carvalho, A., Pires, C., Pires, H. O., Pires, V. C., and Ramalho, C.: 20th Century Portuguese Climate and Climate Scenarios. In: Climate Changes in Portugal: Scenarios, Impacts and Adaptation Measures (SIAM Project), Santos, F. D., Forbes, K., and Moita, R. (Eds.), Gradiva, 2002.

Moberg, A., Sonechkin, D. M., Holmgren, K., Datsenko, N. M., and Karlén, W. H.: Highly variable Northern Hemisphere temperatures reconstructed from low- and high-resolution data, Nature, 433, 613-617, 2005.

Moita, T.: Estrutura, Variabilidade e Dinamica do Fitoplancton na Costa de Portugal Continental., 2001.article compilation, Faculdade de Ciencias da Universidade de Lisboa, University of Lisbon, Lisbon, 272 pp., 2001.

Moore, P. D., Webb, J. A., and Collinson, M. E.: Pollen analysis, Blackwell scientific publication, Oxford, 1991.

Morellón, M., Valero-GarcÉS, B., Anselmetti, F., Ariztegui, D., Schnellmann, M., Moreno, A. N. A., Mata, P., Rico, M., and Corella, J. P.: Late Quaternary deposition and facies model for karstic Lake 
Clim. Past Discuss., doi:10.5194/cp-2017-39, 2017

Manuscript under review for journal Clim. Past

Discussion started: 16 March 2017

(c) Author(s) 2017. CC-BY 3.0 License.

Moreno, A., Morellón, M., Martín-Puertas, C., Frigola, J., Canals, M., Cacho, I., Corella, J. P., Pérez, A., Belmonte, Á., Vegas-Vilarrúbia, T., González-Sampériz, P., and Valero-Garcés, B. L.: Was there a common hydrological pattern in the Iberian Peninsula region during the Medieval Climate Anomaly?, PAGES news, 19, 16-18, 2011.

5 Moreno, A., Valero-Garcés, B. L., González-Sampériz, P., and Rico, M.: Flood response to rainfall variability during the last 2000 years inferred from the Taravilla Lake record (Central Iberian Range, Spain), Journal of Paleolimnology, 40, 943-961, 2008.

Müller, P. J., Kirst, G., Ruhland, G., von Storch, I., and Rosell-Meré, A.: Calibration of the alkenone paleotemperature index UK'37 based on core-pops from the eastern South Atlantic and the global ocean (60ํN-60으), Geochimica et Cosmochimica Acta, 62, 1757-1772, 1998.

Naughton, F., Sanchez Goñi, M. F., Desprat, S., Turon, J. L., Duprat, J., Malaizé, B., Joli, C., Cortijo, E., Drago, T., and Freitas, M. C.: Present-day and past (last 25000 years) marine pollen signal off western Iberia, Marine Micropaleontology, 62, 91-114, 2007.

Naughton, F., Sánchez Goñi, M. F., Kageyama, M., Bard, E., Cortijo, E., Desprat, S., Duprat, J., Malaizé, B., Joli, C., Rostek, F., and Turon, J.-L.: Wet to dry climatic trend in north western Iberia within Heinrich events, Earth and Planetary Science Letters, 284, 329-342, 2009.

Oliveira, P. B., Moita, T., Catarino, R., and Silva, A. J. d.: Wintertime SST and Chla off NW Iberian shelf from satellite and insitu data, Amsterdam, 24-28 September 2007,2007.

Otero, P., Ruiz-Villarreal, M., and Peliz, A.: Variability of river plumes off Northwest Iberia in response to wind events, Journal of Marine Systems, 72, 238-255, 2008.

Palter, J. B.: The Role of the Gulf Stream in European Climate. , Annu. Rev. Marine Sci. , 7, 113-137, 2015.

Pardo, P. C., Padín, X. A., Gilcoto, M., Farina-Busto, L., and Pérez, F. F.: Evolution of upwelling systems coupled to the long-term variability in sea surface temperature and Ekman transport, Climate Research, 48, 231:246, 2011.

Peliz, Á.: Fronts, jets, and counter-flows in the Western Iberian upwelling system, Journal of Marine Systems, 35, 61-77, 2002.

Peliz, Á., Dubert, J., Santos, A. M. P., Oliveira, P. B., and Le Cann, B.: Winter upper ocean circulation in the Western Iberian Basin-Fronts, Eddies and Poleward Flows: an overview, Deep Sea

Research Part I: Oceanographic Research Papers, 52, 621-646, 2005.

Pena, L. D., Francés, G., Diz, P., Esparza, M., Grimalt, J. O., Nombela, M. A., and Alejo, I.: Climate fluctuations during the Holocene in NW Iberia: High and low latitude linkages, Continental Shelf Research, 30, 1487-1496, 2010. 
Clim. Past Discuss., doi:10.5194/cp-2017-39, 2017

Manuscript under review for journal Clim. Past

Discussion started: 16 March 2017

(c) Author(s) 2017. CC-BY 3.0 License.

Discussions

(c) (i)

Pérez, F. F., Padín, X., Pazos, Y., Gilcoto, M., Cabanas, J. M., Pardo, P., Doval, D., and Farina-Bustos, L.: Plankton response to weakning of the Iberian coastal upwelling, Global Change Biology, 16, 12581267, 2010.

R Core Team: A language and environment for statistical computing. R Foundation for Statistical

5 Computing,. Vienna, Austria, 2013.

Reille, M.: Pollen et spores d'Europe et d'Afrique du Nord, Laboratoire de botanique historique et palynologie, Marseille, 1992.

Reimer, P., Baillie, M., Bard, E., Bayliss, A., Beck, J., Bertrand, C., Blackwell, P., Buck, C., Burr, G., Cutler, K., Damon, P., Edwards, R., Fairbanks, R., Friedrich, M., Guilderson, T., Hughen, K., Kromer, B., McCormac, F., Manning, Ramsey, C. B., Reimer, R., Remmele, S., Southon, J., Stuiver, M., Talamo, S., Taylor, F., Plicht, J. v. d., and Weyhenmeyer, C.: Marine04 Marine radiocarbon age calibration, 26 - 0 ka BP, Radiocarbon, 46, 1029-1058, 2004.

Relvas, P. and Barton, E. D.: Mesoscale patterns in the Cape São Vicente (Iberian Peninsula) upwelling region, Journal of Geophysical Research, 107, 28/21-23, 2002.

15 Relvas, P., Luis, J., and Santos, A. M. P.: Importance of the mesoscale in the decadal changes observed in the northern Canary upwelling system, Geophys. Res. Lett., 36, L22601 2009.

Rodrigues, T., Grimalt, J. O., Abrantes, F. G., Flores, J. A., and Lebreiro, S. M.: Holocene interdependences of changes in sea surface temperature, productivity, and fluvial inputs in the Iberian continental shelf (Tagus mud patch), Geochemistry, Geophysics, Geosystems, 10, n/a-n/a, 2009.

Romero-Viana, L., Julià, R., Schimmel, M., Camacho, A., Vicente, E., and Miracle, M. R.:

Reconstruction of annual winter rainfall since A.D. 1579 in centraleastern Spain based on calcite laminated sediment from Lake La Cruz, Climate Change, 107, 343-361, 2011.

Sabine, C. L.: The Oceanic Sink for Anthropogenic CO2, Science, 305, 367-371, 2004.

Saenger, C., Came, R. E., Oppo, D. W., Keigwin, L. D., and Cohen, A. L.: Regional climate variability in the western subtropical North Atlantic during the past two millennia, Paleoceanography, 26, n/a$\mathrm{n} / \mathrm{a}, 2011$.

Sánchez, R. F. and Relvas, P.: Spring-summer climatological circulation in the upper layer in the region of Cape St. Vincent, Southwest Portugal

, ICES J. Mar. Sci., 60, 1232-1250, 2003.

Sánchez-López, G., Hernández, A., Pla-Rabes, S., Trigo, R. M., Toro, M., Granados, I., Sáez, A., Masqué, P., Pueyo, J. J., Rubio-Inglés, M. J., and Giralt, S.: Climate reconstruction for the last two millennia in central Iberia: The role of East Atlantic (EA), North Atlantic Oscillation (NAO) and their interplay over the Iberian Peninsula, Quaternary Science Reviews, 149, 135-150, 2016. 
Clim. Past Discuss., doi:10.5194/cp-2017-39, 2017

Manuscript under review for journal Clim. Past

Discussion started: 16 March 2017

(c) Author(s) 2017. CC-BY 3.0 License.

Schurer, A. P., Tett, S. F. B., and Hegerl, G. C.: Small influence of solar variability on climate over the past millennium, Nature Geoscience, 7, 104-108, 2014.

Solanki, S. K., Usoskin, I. G., Kromer, B., Schüssler, M., and Beer, J.: An unusually active Sun during recent decades compared to the previous 11,000 years, Nature, 431, 1084-1087, 2004.

5 Steinhilber, F., Abreu, J. A., Beer, J., Brunner, I., Christl, M., Fischer, H., Heikkilä, U., Kubik, P. W., Mann, M., McCracken, K. G., H. Miller, Miyahara, H., Oerter, H., and Wilhelms, F.: 9,400 years of cosmic radiation and solar activity from ice cores and tree rings., Proceedings of the National Academy of Sciences, doi: doi:10.1073/pnas.1118965109 2012. 2012.

Stocker, T. and Mysak, L.: Climatic fluctuations on the century time scale: A review of high resolution proxy data and possible mechanisms, Climatic Change, 20, 227-250, 1992.

Teles-Machado, A., Peliz, Á., McWilliams, J. C., Cardoso, R. M., Soares, P. M. M., and Miranda, P. M. A.: On the year-to-year changes of the Iberian Poleward Current, Journal of Geophysical Research: Oceans, 120, 4980-4999, 2015.

Torrence, C. and Compo, G. P.: A practical guide to wavelet analysis, Bulletin of the American Meteorological Society, 79, 61-78, 1998.

Touchan, R., Xoplaki, E., Funkhouser, G., Luterbacher, J., Hughes, M. K., Erkan, N., Akkemik, Ü., and Stephan, J.: Reconstructions of Spring/Summer Precipitation for the Eastern Mediterranean from Tree-Ring Widths and its Connection to Large-Scale Atmospheric Circulation, Climate Dynamics, 25, 75-98, 2005.

Trigo, R. M. and DaCamara, C. C.: Circulation Weather Types and Their influence on the Precipitation Regime in Portugal, International Journal of Climatology, 20, 1559-1581, 2000. Trigo, R. M., Pozo-Vázquez, D., Osborn, T. J., Castro-Díez, Y., Gámiz-Fortis, S., and Esteban-Parra, M. J.: North Atlantic oscillation influence on precipitation, river flow and water resources in the Iberian Peninsula, International Journal of Climatology, 24, 925-944, 2004.

Trouet, V., Esper, J., Graham, N. E., Baker, A., Scourse, J. D., and Frank, D. C.: Persistent Positive North Atlantic Oscillation Mode Dominated the Medieval Climate Anomaly, Science, 324, 78, 2009. Tullot, I.: Historical documentation of Spain's climate, Madrid, 1988.

Turner, T. E., Swindles, G. T., Charman, D. J., Langdon, P. G., Morris, P. J., Booth, R. K., Parry, L. E., and Nichols, J. E.: Solar cycles or random processes? Evaluating solar variability in Holocene climate records, Scientific Reports, 6, 23961, 2016.

Usoskin, I. G., Solanki, S. K., and Kovaltsov, G. A.: Grand minima of solar activity during the last millennia, Proceedings of the International Astronomical Union, 7, 372-382, 2011.

Valero-Garcés, B. L., González-Sampériz, P., Navas, A., Machín, J., Mata, P., Delgado-Huertas, A., Bao, R., Moreno, A., Carrión, J. S., Schwalb, A., and González-Barrios, A.: Human Impact Since Medieval 
Clim. Past Discuss., doi:10.5194/cp-2017-39, 2017

Manuscript under review for journal Clim. Past

Discussion started: 16 March 2017

(c) Author(s) 2017. CC-BY 3.0 License.

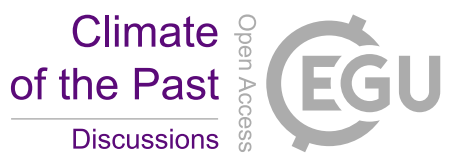

Times and Recent Ecological Restorationin a Mediterranean Lake: The Laguna Zoñar, Southern Spain, Journal of Paleolimnology, 35, 441-465, 2006.

Varzeano, J.: Há um século a grande cheia do Guadiana provocou tragédia em Alcoutim. In: Jornal do Algarve, Vila Real de Santo António, 1976.

5 Villanueva, J.: Estudi de les variaciones climàtiques i oceanogràfiques a l`atlantic Nord Durant els últims 300.000 anys mitjançant l`análisi de marcadores moleculars, 1996. Dep.Química Ambiental, Universitat de Barcelona, Barcelona, 186 pp., 1996.

Villanueva, J. and et, a.: A biomarker approach to the organic matter deposited in the North Atlantic during the last climatic cycle, Geochimica et Cosmochimica Acta, 61, 4633-4646, 1997.

10 Villanueva, J. and Grimalt, J. O.: Gas Chromatographic Tuning of the UK37 Paleothermometer, Analytical Chemistry, 69, 3329-3332, 1997.

Vinther, B. M., K. K. Andersen, A. W. Hansen, T. Schmith, and Jones, P. D.: Improving the Gibraltar/Reykjavik NAO index, GEOPHYSICAL RESEARCH LETTERS, 30, doi:10.1029/2003GL018220, 2003.

15 Wang, C. and Dong, S.: Is the basin-wide warming in the North Atlantic Ocean related to atmospheric carbon dioxide and global warming?, Geophysical Research Letters, 37, n/a-n/a, 2010.

Yamamoto, A. and Palter, J. B.: The absence of an Atlantic imprint on the multidecadal variability of wintertime European temperature, Nature Communications, 7, 10930, 2016.

20 Zampieri, M., Toreti, A., Schindler, A., Scoccimarro, E., and Gualdi, S.: Atlantic multi-decadal oscillation influence on weather regimes over Europe and the Mediterranean in spring and summer, Global and Planetary Change, doi: http://dx.doi.org/10.1016/j.gloplacha.2016.08.014, 2016. 2016.

Zhang, R.: Anticorrelated multidecadal variations between surface and subsurface tropical North Atlantic, Geophysical Research Letters, 34, n/a-n/a, 2007. 
Clim. Past Discuss., doi:10.5194/cp-2017-39, 2017

Climate

Manuscript under review for journal Clim. Past

Discussion started: 16 March 2017

(c) Author(s) 2017. CC-BY 3.0 License.

Discussions

\section{(c) (i)}

\begin{tabular}{|c|c|c|c|c|c|c|c|c|}
\hline Site & ID & ater depth (r) & Lat $\mathrm{N}$ & Long W & Core Type & Cruise & $S R(\mathrm{~mm} / \mathrm{rr})$ & Age Model \\
\hline Galiza & GeoB11033-1 & 1873 & 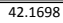 & $\begin{array}{ll}-9.5360 \\
\end{array}$ & Box & Galiomar P342 & 0.4 & This work \\
\hline Minho & DIVA09 GC & 119 & 41.9168 & -9.0735 & Gravity & Sarmento de Gamboa & 0.5 & This work \\
\hline Porto & PO287-6G & 84 & 41.3356 & -8.9888 & Gravity & RV Poseidon - PALEO1 & 6.3 & Abrantes et al., (2011) \\
\hline Tagus - Lisbon & D13902 & 90 & 38.5540 & -9.3355 & Long Piston & RV Discovery 249 & 7.0 & Abrantes, F.,et al, (2005) \\
\hline Tagus - Lisbon & PO287-26-1B, 26G & 96 & 38.5582 & -9.3640 & Box/Garvity & RV Poseidon - PALEO1 & 7.0 & Abrantes, F.,et al, (2005) \\
\hline Tagus - Lisbon & D13882 & 88 & 38.6450 & -9.4542 & Long Piston & RV Discovery 249 & 0.2 & Rodrigues et al, (2009) \\
\hline Algarve - Faro & POPEI VC2B & 96 & 36.8800 & -8.0700 & Vibrocore & NRP Auriga - POPEI0108 & 1.2 & This work \\
\hline
\end{tabular}

Table 1 - Geographic location, water depth, sampling cruise, sedimentation rate (SR) and age model origin for the eight studied cores.

5

\begin{tabular}{|c|c|c|c|c|c|c|c|}
\hline Core ID and depth $(\mathrm{cm})$ & Laboratory code & $\begin{array}{l}\text { Sample } \\
\text { Type }\end{array}$ & $\begin{array}{c}\text { Conventional }{ }^{14} \mathrm{C} \\
\text { age (BP) }\end{array}$ & error & $\begin{array}{l}\text { Calibrated age ranges at } \\
95 \% \text { confidence intervals }\end{array}$ & Age AD & Laboratory \\
\hline $\begin{array}{l}\text { GeoB11033-1 } \\
27-28.5\end{array}$ & OS-97151 & Foraminifera & 2430 & 25 & $746-530$ & -638 & National Ocean Sciences AMS - WHOI \\
\hline DIVA 09 CG & & & & & & & \\
\hline & KIA 42919 & Mollusk shell & 465 & 25 & 1841-1859 & 1864 & Leibniz Labor - Kiel \\
\hline $48-49$ & OS-97148 & Foraminifera & 1270 & 25 & $1057-1211$ & 1133 & National Ocean Sciences AMS - WHOI \\
\hline $57-58$ & KIA 42920 & Mollusk shell & 1730 & 30 & $602-728$ & 660 & Leibniz Labor - Kiel \\
\hline $68-69$ & OS-97149 & Foraminifera & 1990 & 25 & $298-482$ & 400 & National Ocean Sciences AMS - WHOI \\
\hline $83-84$ & KIA 42921 & Mollusk shell & 2380 & 30 & $-157-33$ & -60 & Leibniz Labor - Kiel \\
\hline $101-102$ & KIA 42922 & Mollusk shell & 2325 & 30 & $-87-95$ & 11 & Leibniz Labor - Kiel \\
\hline POPEI VC2B & & & & & & & \\
\hline 130.9 & Beta 278216 & Mollusk shell & 1220 & 40 & 1080:1274 & 1184 & Beta Analytics \\
\hline 200.6 & OS-97152 & Foraminifera & 2130 & 25 & $146: 326$ & 233 & National Ocean Sciences AMS - WHOI \\
\hline 270.3 & OS-97143 & Foraminifera & 3020 & 25 & $-902:-783$ & -837 & National Ocean Sciences AMS - WHOI \\
\hline
\end{tabular}

10 Table 2 - Results of 14C accelerator mass spectrometry dating (means \pm SE) of the cores GeoB11033-1 (Galiza), DIVA 09CG (Minho) and POPEI VC2B (Algarve). Ages were reservoir corrected by $400 \mathrm{yr}$ (years before present, yr BP) and converted into calendar years $(\mathrm{AD} / \mathrm{CE})$.

15

\begin{tabular}{|l|c|c|c|c|c|c|}
\hline & \multirow{2}{*}{ Common Era } & \multicolumn{5}{|c|}{ Mean SST } \\
\cline { 3 - 7 } & & Galiza & Minho & Douro & Tejo & Algarve \\
\hline Roman - Dark Ages & $<900$ & 16.0 & 16.5 & - & 17.5 & 19.1 \\
Medieval Warm Period & $900-1300$ & 16.6 & 16.2 & 15.3 & 17.1 & 18.7 \\
Little Ice Age & $1350-1850$ & 16.1 & 15.9 & 14.7 & $15.6^{*}$ & 17.8 \\
Modern Times & $>1900$ & 15.5 & - & 14.7 & 15.5 & 18.3 \\
\hline
\end{tabular}

Table 3 - SST mean during major climatic episodes along Atlantic margin of the Iberian Peninsula. Existing sediment hiatus likely 20 affected estimated value. Shades of blue and pink highlight respectively colder and warmer periods. 
Clim. Past Discuss., doi:10.5194/cp-2017-39, 2017

Climate

Manuscript under review for journal Clim. Past

Discussion started: 16 March 2017

(c) Author(s) 2017. CC-BY 3.0 License.

Discussions

\section{(c) (1)}

FLOODS

\begin{tabular}{|c|c|c|c|c|c|c|}
\hline Period/Region & Atlantic Basin & Douro \& Minho & Tejo & Guadiana & References & $\begin{array}{c}\text { Oservations } \\
\end{array}$ \\
\hline MCA & $\begin{array}{l}\mathbf{1 0 0 0 - 1 2 0 0} \\
1150-1290\end{array}$ & $\begin{array}{r}1000-1100 \\
1180-1200 \\
\end{array}$ & $\begin{array}{l}785-1205 \\
1150-1200\end{array}$ & & \begin{tabular}{|l|} 
Benito et al, 2003 \\
Tullot, 1988 \\
Benito et al, 2003b \\
Benito et al, 2010 \\
Benito et al, 2003b \\
Tullot, 1989 \\
\end{tabular} & $\begin{array}{l}\text { Increase magnitude and frequency } \\
\text { Doc Sources } \\
\text { Sediment records } \\
\text { Max from Doc sources } \\
\text { Sediment records } \\
\text { Doc Sources }\end{array}$ \\
\hline LIA & $\begin{array}{r}1590-1610 \\
\\
1730-1810 \\
1730-1760 \\
1780-1810\end{array}$ & $\begin{array}{l}1434-\text { LCF } \\
1450-1470 \\
1545 \text { - LCF } \\
1626-\text { VLCF } \\
1636 \text { - LCF } \\
1778 \text { - LEF }\end{array}$ & $\begin{array}{l}1450-1500 \\
1626-\text { VLEF } \\
1637 \text { - LCE }\end{array}$ & $\begin{array}{c}1434-\text { LCE } \\
1450-1500 \\
1545-\text { LCE } \\
1570-1630 \\
1626-\text { VLCF } \\
\\
1830-1870 \\
1778-\text { LCE }\end{array}$ & \begin{tabular}{|l|} 
Benito et al, 2010 \\
Barriendos and Rodrigo, 2010 \\
Tullot, 1988; \\
Benito et al, 2003 \\
Barriendos and Rodrigo, 2010 \\
Barriendos and Martin-Vide, 1998 \\
Benito et al, 2003b \\
Barriendos and Rodrigo, 2010 \\
Barriendos and Rodrigo, 2010 \\
Benito et al, 2010 \\
Benito et al, 2003b \\
Barriendos and Martin-Vide, 1998 \\
Barriendos and Rodrigo, 2010 \\
Benito et al, 2003b \\
\end{tabular} & \begin{tabular}{|l} 
Sediment records \& Doc Sources \\
Doc Sources \\
Doc Sources \\
High frequency lower magnitude \\
Doc Sources \\
Mediterranean area- Doc Sources \\
Doc Sources \\
Doc Sources \\
Doc Sources \\
Doc Sources \\
Sediment records \& Doc Sources \\
Mediterranean area- Doc Sources \\
Doc Sources \\
Doc Sources
\end{tabular} \\
\hline MODERN & $\begin{array}{l}1870-1900 \\
1930-1950 \\
1960-1980\end{array}$ & $\begin{array}{l}1853 \text { - LEF } \\
1860 \text { - LCF }\end{array}$ & $\begin{array}{r}1670-1950 \\
1950-1980\end{array}$ & $\begin{array}{l}1876 \\
1979 \\
\end{array}$ & \begin{tabular}{|l} 
Barriendos and Rodrigo, 2010 \\
Barriendos and Rodrigo, 2010 \\
Benito et al, 2003b \\
Benito et al, 2003b \\
Benito et al, 2003b \\
Benito et al, 2003; \\
Benito et al, 2003b
\end{tabular} & \begin{tabular}{|l} 
Doc Sources \\
Doc Sources \\
Sediment records \\
Sediment records \\
Sediment records \\
High frequency lower magnitude \\
Doc Sources
\end{tabular} \\
\hline
\end{tabular}

LCF - Large Catastrophic Flood; LEF - Large Extraordinary Flood; VLCF - Very Large Catastrophic Flood; VLEF - Very Large Extraordinary Event

Bold - Catastrophic Event

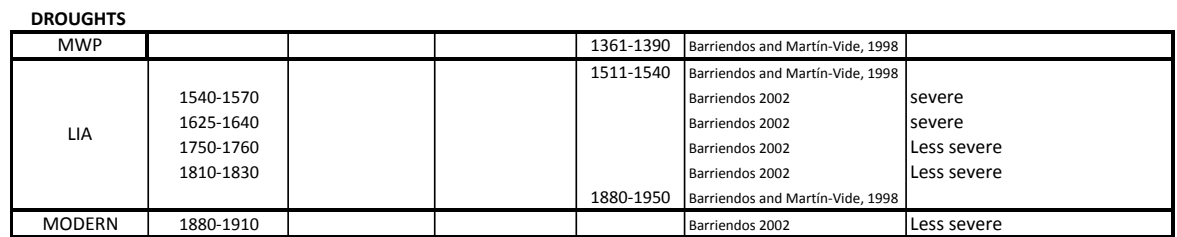

Table 4 - Compilation of flooding and drought events on the western Iberian Peninsula, according to published information. 
Clim. Past Discuss., doi:10.5194/cp-2017-39, 2017

Manuscript under review for journal Clim. Past

Discussion started: 16 March 2017

(c) Author(s) 2017. CC-BY 3.0 License.

(c) (i)

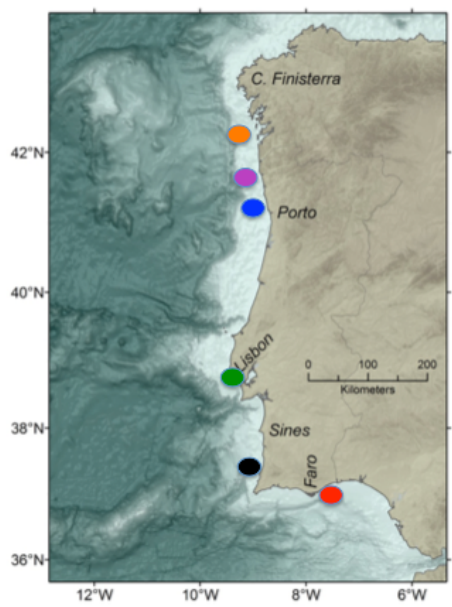

Figure 1 -Cores location over Iberian Margin bathymetry. Geoß11033-1 / Galiza in orange, DIVA09 GC / Minho in magenta, PO287-6B, -6G / Porto (Douro Mud Belt) in blue, PO287-26B, -26G, D130902, D13882 Lisbon (Tagus Mud Belt) in green, and POPEI VC2B/ Algarve in red. The color selected for each region will be applied in all figures.

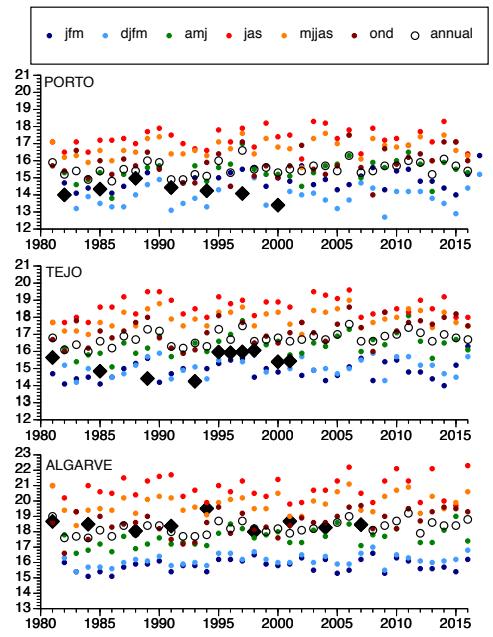

Figure 2 - Comparison of SST stacks constructed using all the cores (total - black), without the Tagus cores (effect of existing hiatus - green), without the Popei record (effect of different coccolithophores generating process - red) and considering only the northern sites (Galiza, Minho and Porto - blue) 
Clim. Past Discuss., doi:10.5194/cp-2017-39, 2017

Manuscript under review for journal Clim. Past

Discussion started: 16 March 2017

(c) Author(s) 2017. CC-BY 3.0 License.

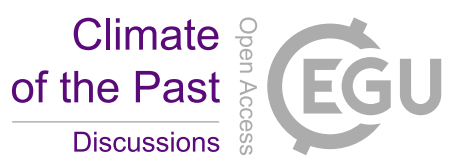

(c) (i)
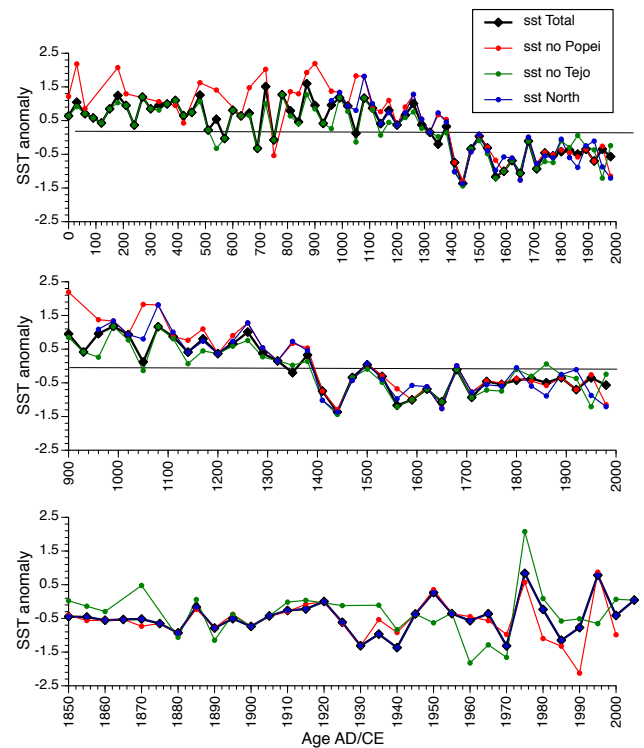

Figure 3 - Comparison of alkenone-derived sea surface temperature (SST - black diamonds) measured in cores PO287-6B, PO287-26B and POPEI with annual, seasonal average, NAO winter (djfm) and upwelling season (mjjas) satellite derived SST at the three sites location. 
Clim. Past Discuss., doi:10.5194/cp-2017-39, 2017

Manuscript under review for journal Clim. Past

Discussion started: 16 March 2017

(c) Author(s) 2017. CC-BY 3.0 License.

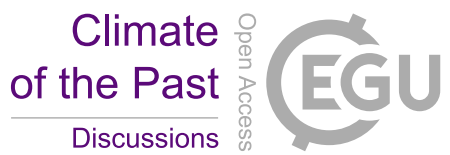

(c) (i)

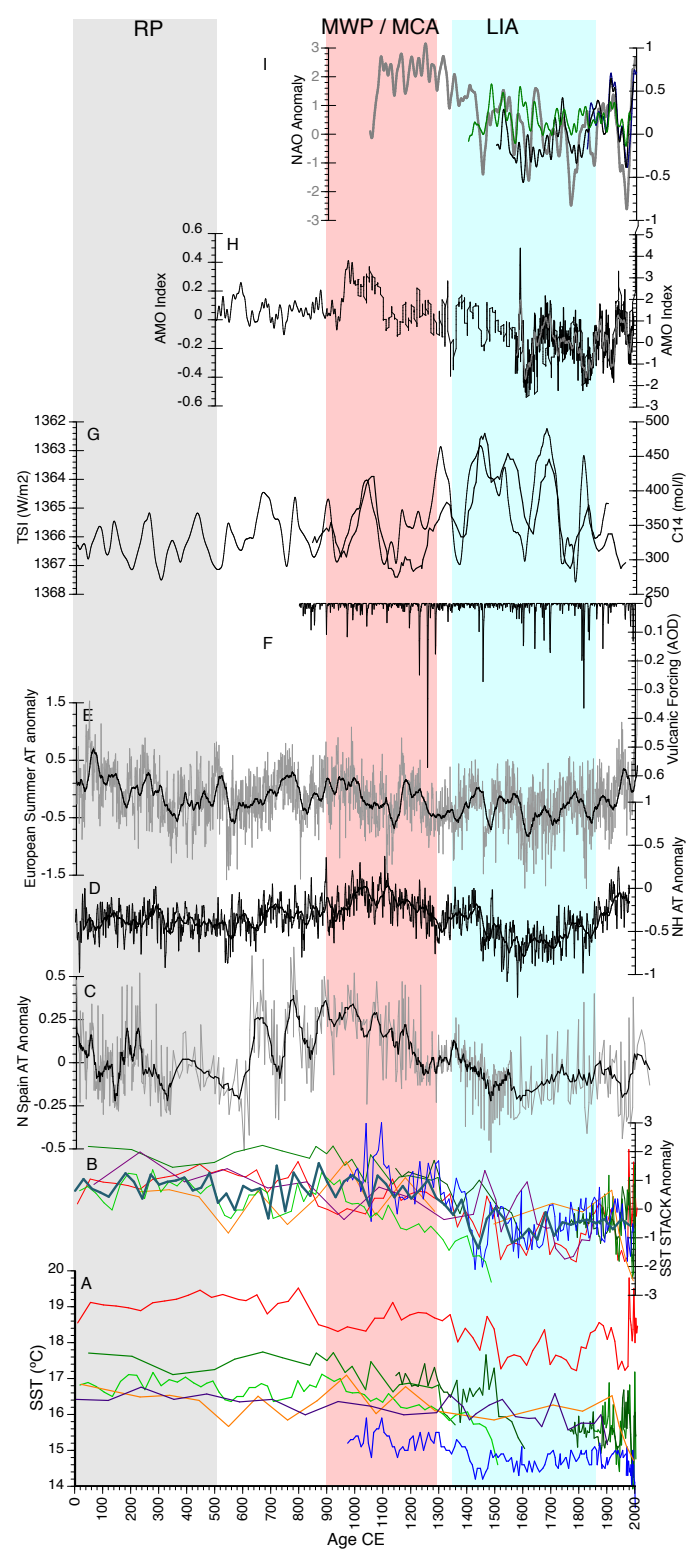

Figure 4 - Comparison of SST along the last 2,000 years at sites Galiza (magenta), Minho (orange), Porto (blue), Lisbon (green) and Algarve (red) (A); SST stack constructed from all Iberian margin records (B); northern Hemisphere annual mean atmospheric temperature anomaly (Moberg et al., 2005) (C); northern Spain atmospheric temperature anomaly (Martín-Chivelet et al., 2011) (D); European spring-fall atmospheric temperature anomaly (Luterbacher et al., 2016) (E); vulcanic activity as aerosol optical depth (Crowley and Unterman, 2013) (F); radionuclide-derived total solar irradiance (TSI) (Bard et al., 2007) and ${ }^{14} \mathrm{C}$ estimated production (Marchal, 2005) (G); northern Atlantic Ocean SST anomaly, AMO index (gray, (Mann et al., 2010) and (black, Gray et al., 2004) (H); NAO index (Luterbacher et al., 2002) and (Trouet et al., 2009) (I). Light grey band marks the Roman Period (RP), the pink band marks the Medieval Warm Period (MWP/MCA); the blue band marks the Little Ice Age (LIA). 
Clim. Past Discuss., doi:10.5194/cp-2017-39, 2017

Climate

Manuscript under review for journal Clim. Past

Discussion started: 16 March 2017

(c) Author(s) 2017. CC-BY 3.0 License.

Discussions

\section{(c) (i)}

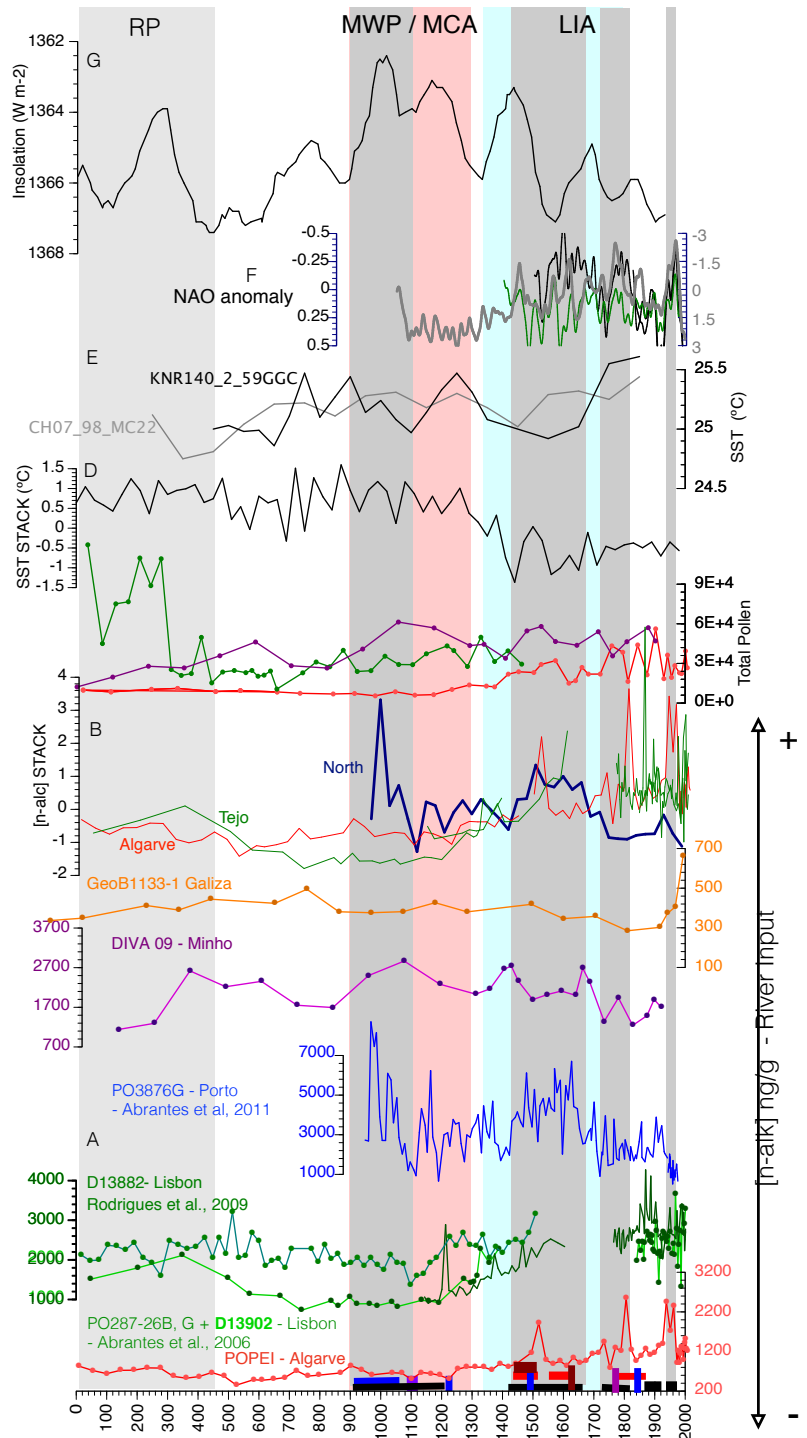

- Atlantic Basin Floodind

- Douro and Minho Flooding

Mediterranean Coast / Guadiana

Figure 5 - [n-alc] variability along the last millennium and at the 5 different sites of the Iberian Atlantic margin (A); the [n-alc]

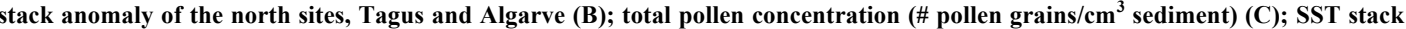
anomaly (D); SST NW Atlantic cores KNR140-2-59GGC and CH07-98-MC22 (Saenger et al., 2011) (E); instrumental NAO index (black line), Luterbacher reconstruction (black line; Luterbacher et al. 2002), Cook reconstruction (green line; (Cook et al., 2002) and (gray line; Trouet et al, 2009) (F); Radionuclide-derived total solar irradiance (TSI) (Bard et al., 2007) (G). Grey bands mark the periods of Atlantic flooding as listed in Table 4. 
Clim. Past Discuss., doi:10.5194/cp-2017-39, 2017

Manuscript under review for journal Clim. Past

Discussion started: 16 March 2017

(c) Author(s) 2017. CC-BY 3.0 License.

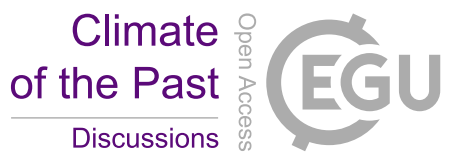

(c) (i)

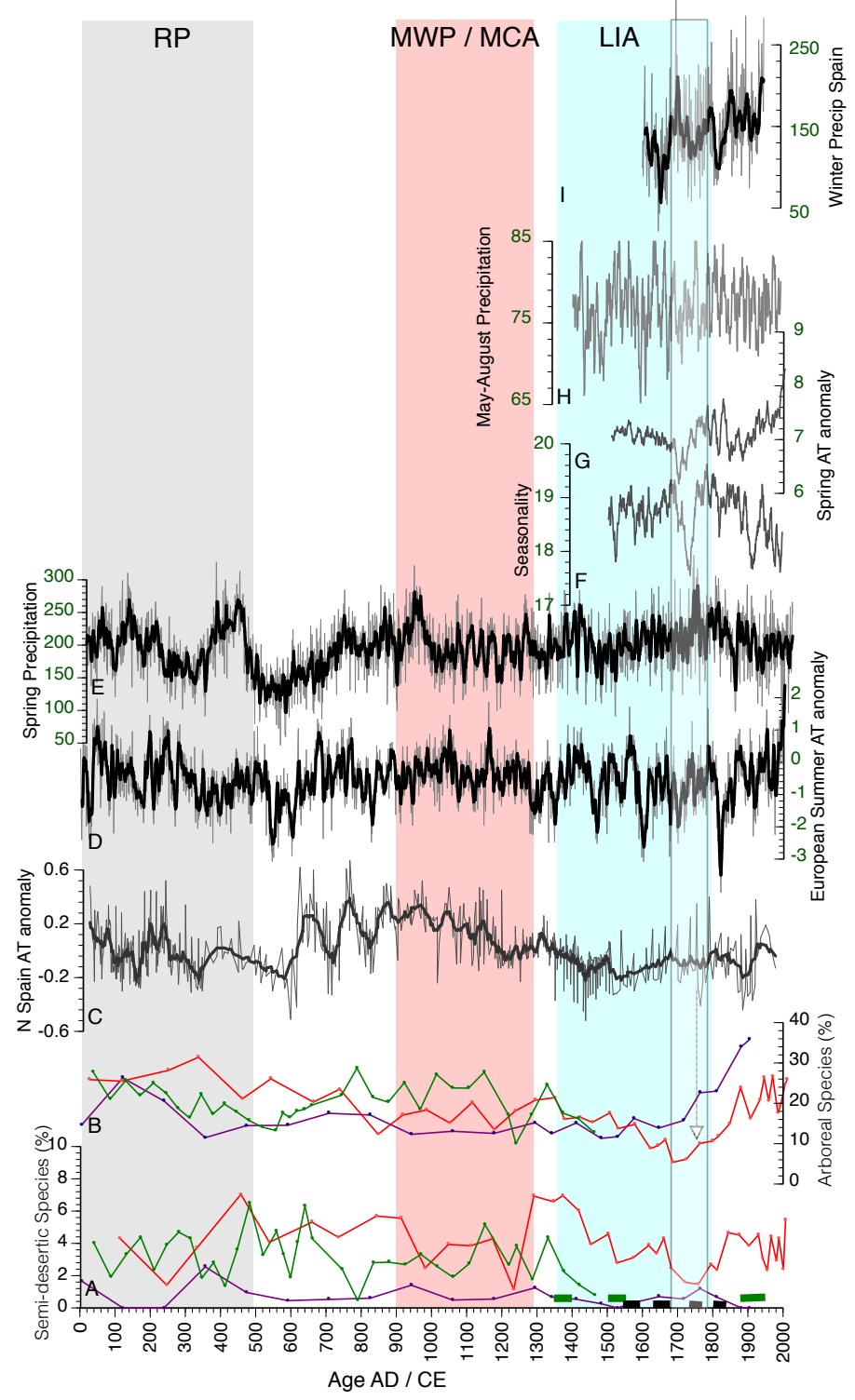

Figure 6 - Variability of semi-desert plants percent percentages along the 2,000 yr record of cores Diva, Tejo and Popei (A); arboreal species percent abundance (B); northern Spain atmospheric temperature anomaly (Martín-Chivelet et al., 2011) (C); European spring-fall atmospheric temperature anomaly (Luterbarher et al., 2016) (D); Spring Precipitation Central Europe (Büntgen et al., 2011) (E): European Seasonality and Spring AT (Luterbacher et al., 2004) (F, G); may-august Precipitation (Touchan et al., 2005) (H); winter (djfm) Precipitation (Romero-Viana et al., 2011) (I). 
Clim. Past Discuss., doi:10.5194/cp-2017-39, 2017

Manuscript under review for journal Clim. Past

Discussion started: 16 March 2017

(c) Author(s) 2017. CC-BY 3.0 License.

(c) (i)
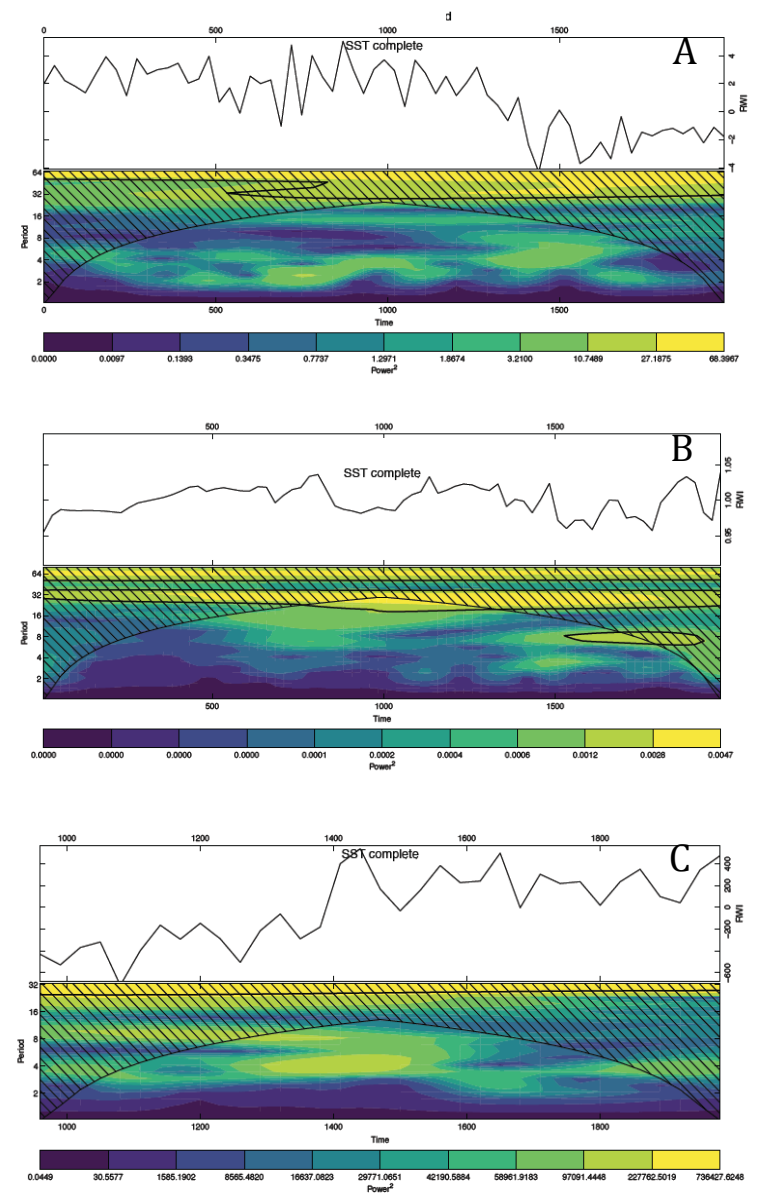

Figure 7 - The continuous wavelet power spectrum of the SST STACK (A); the Algarve SST record (B); and the north SST STACK (C). The thick black contour designates the $95 \%$ confidence level and the lighter shaded area represents the cone of influence (COI) where edge effects might distort the results. 
Clim. Past Discuss., doi:10.5194/cp-2017-39, 2017

Manuscript under review for journal Clim. Past

Discussion started: 16 March 2017

(c) Author(s) 2017. CC-BY 3.0 License.

(c) ${ }_{\mathrm{By}}$
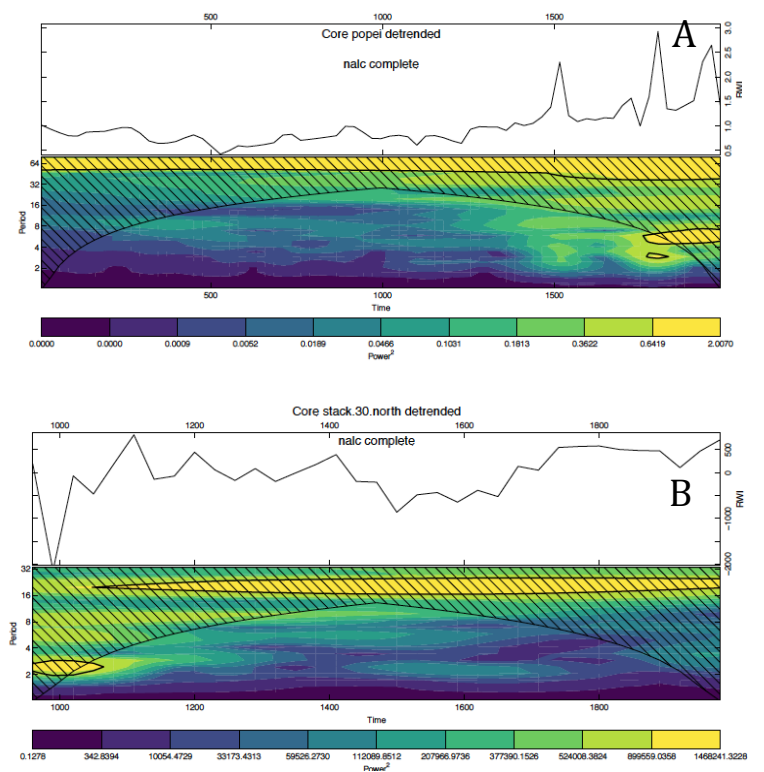

Figure 8 - The continuous wavelet power spectrum of the Algarve [n-alc] record (A) and the north [n-alc] STACK (B). The thick black contour designates the $\mathbf{9 5 \%}$ confidence level and the lighter shaded area represents the cone of influence (COI) where edge 5 effects might distort the results. 